\title{
Missing $\mathrm{SO}_{2}$ oxidant in the coastal atmosphere? - observations from high-resolution measurements of $\mathrm{OH}$ and atmospheric sulfur compounds
}

\author{
H. Berresheim ${ }^{1}$, M. Adam ${ }^{1}$, C. Monahan 1 , C. O'Dowd ${ }^{1}$, J. M. C. Plane ${ }^{2}$, B. Bohn ${ }^{3}$, and F. Rohrer ${ }^{3}$ \\ ${ }^{1}$ School of Physics \& Centre for Climate and Air Pollution Studies, National University of Ireland, Galway, Ireland \\ ${ }^{2}$ School of Chemistry, University of Leeds, Leeds, UK \\ ${ }^{3}$ Institute for Energy and Climate Research (IEK-8), Research Center Jülich, Jülich, Germany \\ Correspondence to: F. Rohrer (f.rohrer@fz-juelich.de)
}

Received: 13 December 2013 - Published in Atmos. Chem. Phys. Discuss.: 15 January 2014

Revised: 4 October 2014 - Accepted: 7 October 2014 - Published: 20 November 2014

\begin{abstract}
Diurnal and seasonal variations of gaseous sulfuric acid $\left(\mathrm{H}_{2} \mathrm{SO}_{4}\right)$ and methane sulfonic acid (MSA) were measured in NE Atlantic air at the Mace Head atmospheric research station during the years 2010 and 2011. The measurements utilized selected-ion chemical ionization mass spectrometry (SI/CIMS) with a detection limit for both compounds of $4.3 \times 10^{4} \mathrm{~cm}^{-3}$ at $5 \mathrm{~min}$ signal integration. The $\mathrm{H}_{2} \mathrm{SO}_{4}$ and MSA gas-phase concentrations were analyzed in conjunction with the condensational sink for both compounds derived from $3 \mathrm{~nm}$ to $10 \mu \mathrm{m}$ (aerodynamic diameter) aerosol size distributions. Accommodation coefficients of 1.0 for $\mathrm{H}_{2} \mathrm{SO}_{4}$ and 0.12 for MSA were assumed, leading to estimated atmospheric lifetimes on the order of 7 and $25 \mathrm{~min}$, respectively. With the SI/CIMS instrument in $\mathrm{OH}$ measurement mode alternating between $\mathrm{OH}$ signal and background (non-OH) signal, evidence was obtained for the presence of one or more unknown oxidants of $\mathrm{SO}_{2}$ in addition to $\mathrm{OH}$. Depending on the nature of the oxidant(s), its ambient concentration may be enhanced in the CIMS inlet system by additional production. The apparent unknown $\mathrm{SO}_{2}$ oxidant was additionally confirmed by direct measurements of $\mathrm{SO}_{2}$ in conjunction with calculated $\mathrm{H}_{2} \mathrm{SO}_{4}$ concentrations. The calculated $\mathrm{H}_{2} \mathrm{SO}_{4}$ concentrations were consistently lower than the measured concentrations by a factor of $4.7 \pm 2.4$ when considering the oxidation of $\mathrm{SO}_{2}$ by $\mathrm{OH}$ as the only source of $\mathrm{H}_{2} \mathrm{SO}_{4}$. Both the $\mathrm{OH}$ and the background signal were also observed to increase significantly during daytime aerosol nucleation events, independent of the ozone photolysis frequency, $J\left(\mathrm{O}^{1} \mathrm{D}\right)$, and were followed by
\end{abstract}

peaks in both $\mathrm{H}_{2} \mathrm{SO}_{4}$ and MSA concentrations. This suggests a strong relation between the unknown oxidant(s), $\mathrm{OH}$ chemistry, and the atmospheric photolysis and photooxidation of biogenic iodine compounds. As to the identity of the atmospheric $\mathrm{SO}_{2}$ oxidant(s), we have been able to exclude $\mathrm{ClO}$, $\mathrm{BrO}, \mathrm{IO}$, and $\mathrm{OIO}$ as possible candidates based on ab initio calculations. Nevertheless, IO could contribute significantly to the observed CIMS background signal. A detailed analysis of this CIMS background signal in context with recently published kinetic data currently suggests that Criegee intermediates (CIs) produced from ozonolysis of alkenes play no significant role for $\mathrm{SO}_{2}$ oxidation in the marine atmosphere at Mace Head. On the other hand, $\mathrm{SO}_{2}$ oxidation by small CIs such as $\mathrm{CH}_{2} \mathrm{OO}$ produced photolytically or possibly in the photochemical degradation of methane is consistent with our observations. In addition, $\mathrm{H}_{2} \mathrm{SO}_{4}$ formation from dimethyl sulfide oxidation via $\mathrm{SO}_{3}$ as an intermediate instead of $\mathrm{SO}_{2}$ also appears to be a viable explanation. Both pathways need to be further explored.

\section{Introduction}

It has been well established that homogeneous oxidation of tropospheric gases is generally dominated by reactions with the hydroxyl $(\mathrm{OH})$ radical during daylight hours and - in regions with significant nitrogen oxide $\left(\mathrm{NO}_{\mathrm{x}}\right)$ concentrations - with the nitrate $\left(\mathrm{NO}_{3}\right)$ radical in the absence of sunlight (Stone et al., 2012). Reactions of molecular oxygen, ozone, 
or peroxy radicals such as $\mathrm{HO}_{2}$ and $\mathrm{RO}_{2}$ ( $\mathrm{R}$ : organic rest molecule) are comparatively slow, with a few exceptions, such as $\mathrm{NO}+\mathrm{HO}_{2}$, which recycles $\mathrm{OH}$ (e.g., Atkinson et al., 2004). Heterogeneous oxidation (on the surface of aerosol particles and in cloud and fog droplets) is dominated by reactions with either dissolved ozone, hydrogen peroxide, or molecular oxygen, the latter pathway being catalyzed by transition metal ions (Harris et al., 2013; Berresheim and Jaeschke, 1986). However, recent studies have revived an interest in the formation and fate of atmospheric Criegee intermediates (radical species produced from reactions of ozone with alkenes; Calvert et al., 2000; Criegee, 1975), which to this day have eluded direct measurements in the atmosphere since Cox and Penkett (1971) first suggested their potentially important role. Field and laboratory measurements (Berndt et al., 2012, 2014; Stone et al., 2014; Taatjes et al., 2014; Mauldin III et al., 2012; Welz et al., 2012) as well as theoretical and modeling studies (Sarwar et al., 2014; Boy et al., 2013; Vereecken et al., 2012) now suggest that the reactivity of these types of radicals towards compounds such as $\mathrm{SO}_{2}$ may have been underestimated by at least 2 orders of magnitude. Therefore, in addition to $\mathrm{OH}$ - or possibly even rivalling $\mathrm{OH}$ chemistry - Criegee intermediates may, under certain conditions, be significant contributors to atmospheric sulfuric acid formation and the production of hygroscopic sulfate particles, which can be activated as cloud condensation nuclei $(\mathrm{CCN})$.

Selected-ion chemical ionization mass spectrometry (SI/CIMS) has been pioneered by Eisele and coworkers (Tanner and Eisele, 1995; Eisele and Tanner, 1991, 1993; Eisele and Berresheim, 1992) for high-time-resolution measurements of $\mathrm{OH}, \mathrm{H}_{2} \mathrm{SO}_{4}, \mathrm{MSA}(\mathrm{g})$ (gaseous methane sulfonic acid), and other compounds in the troposphere. A large number of field studies both on the ground and from the air have been successfully conducted using this technique and have significantly improved our understanding of tropospheric chemistry (e.g., Stone et al., 2012; Huey, 2007; Heard and Pilling, 2003). In some of these studies it has already been conjectured that SI/CIMS may also provide information about the presence of atmospheric oxidants other than $\mathrm{OH}$ by analyzing the background signal recordings obtained in the $\mathrm{OH}$ measurement mode. Specifically, the identity of this "background X oxidant(s)" was speculated to be Criegee intermediates because of their observed reactivity towards $\mathrm{SO}_{2}$ in the measurement system (e.g., Berresheim et al., 2002).

In the present paper we have analyzed 2 years of SI/CIMS measurements made at Mace Head, Ireland, for significant occurrences of such background signals indicating the presence of one or more unknown $\mathrm{SO}_{2}$ oxidants in coastal air which could contribute to $\mathrm{H}_{2} \mathrm{SO}_{4}$ formation (in addition to $\mathrm{OH})$ during day- and nighttime. Furthermore, balance calculations of ambient $\mathrm{H}_{2} \mathrm{SO}_{4}$ levels using measured $\mathrm{SO}_{2}, \mathrm{OH}$, and aerosol particle concentrations have been compared with measured $\mathrm{H}_{2} \mathrm{SO}_{4}$ levels. This allowed us to approximate corresponding contributions to ambient $\mathrm{H}_{2} \mathrm{SO}_{4}$ levels from oxi-

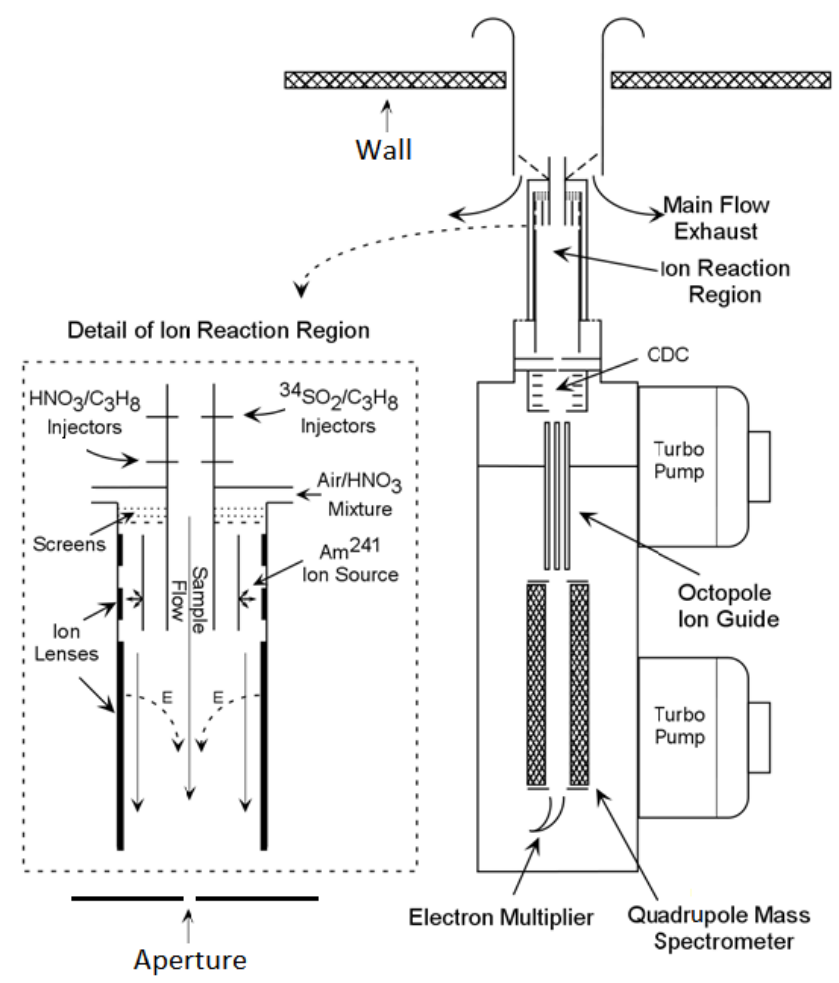

Figure 1. Principle scheme of SI/CIMS components including air inlet (modified from R. L. Mauldin III, personal communication, 2012). Inset shows details of the atmospheric pressure region, with reagent gas flows indicated for measurement of $\mathrm{OH}$ background signal (both ${ }^{34} \mathrm{SO}_{2}$ and $\mathrm{C}_{3} \mathrm{H}_{8}$ are added to the sample air through the two front injectors; see text). Laminar flow conditions with a central flow axis velocity of $0.71 \mathrm{~m} \mathrm{~s}^{-1}$ in both the sample and ionization tubes are generated by a $12 \mathrm{slpm}$ sample flow, $58 \mathrm{slpm}$ total flow (i.e., sample flow plus sheath flow, the latter indicated here by addition of an Air $/ \mathrm{HNO}_{3}$ mixture), and the geometries of the sample tube (diameter $1.9 \mathrm{~cm}$ ) and ionization tube (diameter $4.2 \mathrm{~cm}$ ). The time needed (in each case starting at the first injector) to reach the second injector is $73 \mathrm{~ms}$, to the entrance of the ionization region $115 \mathrm{~ms}$, and to the aperture in front of the mass spectrometer $450 \mathrm{~ms}$.

dation of $\mathrm{SO}_{2}$ by oxidants other than $\mathrm{OH}$ and estimate their relative importance with respect to $\mathrm{OH}$ reactivity.

\section{Experimental}

A principle scheme of the Mace Head CIMS instrument and its operation is shown in Fig. 1. Similar to previously described systems (Berresheim et al., 2000, 2013; Mauldin III et al., 1998, 2012), the aerodynamically shaped main air inlet extrudes retractably through the wall of the building, here towards the open ocean, with a marine wind sector of $190-300^{\circ}$. In the following text, "marine sector" data include only the subset of data consistent with the marine wind sector, NO levels $<50 \mathrm{pptv}$, and/or black carbon concentra- 
tions $<50 \mathrm{ng} \mathrm{m}^{-3}$. From the main air flow (approximately $2.5 \mathrm{~m}^{3} \mathrm{~h}^{-1}$ ) the central region is sampled at $12 \mathrm{slpm}$ through a $1.9 \mathrm{~cm}$ diameter sample flow tube. Two pairs of oppositely arranged capillary stainless steel injectors (the front pair sitting upflow, the rear pair downflow at $5.2 \mathrm{~cm}$ distance from each other) protrude into the sample flow tube. Depending on the operational mode $(\mathrm{OH}$ signal measurement, $\mathrm{OH}$ background measurement, or $\mathrm{H}_{2} \mathrm{SO}_{4}$ and $\mathrm{MSA}(\mathrm{g})$ measurement) selected flows of $\mathrm{SO}_{2}$, propane $\left(\mathrm{C}_{3} \mathrm{H}_{8}\right)$, and $\mathrm{N}_{2}$ (as makeup gas) are added through the injectors to the sample flow.

For measuring an $\mathrm{OH}$ signal, isotopically heavy ${ }^{34} \mathrm{SO}_{2}$ (98.8\%, Eurisotop, Saint-Aubin, France) is introduced through the front injectors and mixed into the sample air flow, resulting in a $\mathrm{SO}_{2}$ mixing ratio of approximately 8 ppmv. At this setting, the $\mathrm{OH}$ lifetime (1/e definition) in the sample flow is $6 \mathrm{~ms}$. The ambient $\mathrm{OH}$ concentration introduced into the CIMS system is completely converted to $\mathrm{H}_{2}^{34} \mathrm{SO}_{4}$ by its reaction with ${ }^{34} \mathrm{SO}_{2}$ within the available reaction time of $\tau_{\text {reac }, \mathrm{OH}}=78 \mathrm{~ms}$ before reaching the rear injectors. Approximately $1 \%$ of the resulting product, $\mathrm{H}_{2}^{34} \mathrm{SO}_{4}$, is converted via chemical ionization at atmospheric pressure by $\mathrm{NO}_{3}^{-}$reactant ions into $\mathrm{H}^{34} \mathrm{SO}_{4}^{-}$product ions, which are then focused and guided by electrical potentials (along with remaining $\mathrm{NO}_{3}^{-}$ ions) through an $80 \mu \mathrm{m}$ aperture into the vacuum mass spectrometry region. The reactant ions are produced in a sheath flow of purified ambient air with added $\mathrm{HNO}_{3}$ passing by a radioactive ${ }^{241} \mathrm{Am}$ alpha emitter (activity: $4.1 \mathrm{MBq}$; Eckert \& Ziegler, Berlin, Germany). Detection of the $\mathrm{H}^{34} \mathrm{SO}_{4}^{-}$ signal at $m / z 99$ following quadrupole mass filtering yields the equivalent concentration of $\mathrm{OH}$ in ambient air. With the same method of ionization applied, ambient sulfuric acid $\left(\mathrm{H}_{2} \mathrm{SO}_{4}\right)$ and methane sulfonic acid $\left(\mathrm{CH}_{3} \mathrm{SO}_{3} \mathrm{H}\right)$, in which sulfur occurs as ${ }^{32} \mathrm{~S}$ at a fraction of 0.95 (Krouse and Grinenko, 1991), are detected at $m / z 97$ and $m / z$ 95, respectively. Time resolution for measuring all three masses is typically $30 \mathrm{~s}$. In general, measurement signals are integrated to 5 min with corresponding detection limits of $1.3 \times 10^{5} \mathrm{~cm}^{-3}$ for $\mathrm{OH}$ and $4.3 \times 10^{4} \mathrm{~cm}^{-3}$ for both $\mathrm{H}_{2} \mathrm{SO}_{4}$ and $\mathrm{MSA}(\mathrm{g})$, respectively (Berresheim et al., 2013; Mauldin III et al., 1998). Further details including calibration procedures can be found in Berresheim et al. (2000). The operational cycle of the CIMS instrument was typically set to measure ambient $\mathrm{OH}$ and $\mathrm{H}_{2} \mathrm{SO}_{4}$ for 5 min during each half hour, followed by 25 min measurements of ambient $\mathrm{H}_{2} \mathrm{SO}_{4}$ and $\mathrm{MSA}(\mathrm{g})$.

Propane $(99.95 \%$, Air Liquide, UK) is introduced into the sample flow through the rear injectors (establishing a mixing ratio of approximately $430 \mathrm{ppmv}$ in the sample flow) to scavenge any $\mathrm{OH}$ which might be recycled from peroxy radicals via reaction with nitric oxide, NO. On average, nighttime $\mathrm{OH}$ measurements showed no statistical difference between the background signal and the $\mathrm{OH}$ signal, suggesting any potential interference by trace contaminants in the propane to be negligible. Due to similar rate constants for $\mathrm{SO}_{2}$ and propane with respect to their reaction with $\mathrm{OH}$ (both ca.
$1 \times 10^{-12} \mathrm{~cm}^{3} \mathrm{~s}^{-1}$ at $298 \mathrm{~K}$; Atkinson et al., 2004), any (recycled) $\mathrm{OH}$ molecules are completely scavenged by propane instead of $\mathrm{SO}_{2}$ from this point, i.e., downflow from the rear injectors. Due to the very low NO mixing ratios in marine air at Mace Head (Berresheim et al., 2013), contributions to the measurement signal from the recycling of $\mathrm{OH}$ are expected to be negligible.

The background (BG) signal in the $\mathrm{OH}$ measurement mode is evaluated by switching the propane flow from the rear to the front injectors. This prevents formation of $\mathrm{H}^{34} \mathrm{SO}_{4}^{-}$ions resulting from ${ }^{34} \mathrm{SO}_{2}+\mathrm{OH}$ reaction in the system. Theoretically, any background counts observed at $\mathrm{m} / \mathrm{z} 99$ under these conditions should only reflect the $4.2 \%$ fraction of ${ }^{34} \mathrm{~S}$ occurring in ambient $\mathrm{H}_{2} \mathrm{SO}_{4}$. If a significantly higher $\mathrm{BG}$ count is observed, this might indicate the presence of a compound with stronger electron affinity than $\mathrm{HNO}_{3}$ ending up as a product ion at $m / z$ 99. However, experiments conducted without ${ }^{34} \mathrm{SO}_{2}$ in the system never showed any evidence for the existence of such a compound. Therefore, observations of significant BG signals (above the ambient $4.2 \%$ $\mathrm{H}^{34} \mathrm{SO}_{4}^{-}$signal) suggested the presence of one or more unknown oxidants (X oxidants) converting ${ }^{34} \mathrm{SO}_{2}$ to $\mathrm{H}_{2}^{34} \mathrm{SO}_{4}$ in the CIMS system without appreciably reacting with propane. Indeed, this interpretation was corroborated by stopping the $\mathrm{SO}_{2}$ injection to the sample flow and observing a corresponding reduction in the $m / z 99 \mathrm{BG}$ signal. Furthermore, with $\mathrm{SO}_{2}$ in the system, the propane flow through the front injector was successively increased from relatively low values up to the operational setting for measuring the $\mathrm{BG}$ signal. Before reaching this setting the signal was found to tail off to a background level corresponding to the complete removal of $\mathrm{OH}$. Increasing the propane flow did not further alter the BG signal. Also, no significant BG signal was observed during calibration runs, in which $\mathrm{OH}$ concentrations on the order of $10^{7}-10^{8} \mathrm{~cm}^{-3}$ were produced from UV photolysis of water vapor in ambient sample air, thus further corroborating the absence of any artifact process contributing to this signal.

The total reaction time, $\tau_{\text {reac, } \mathrm{X}}$, available to this unknown $\mathrm{X}$ oxidant to react with $\mathrm{SO}_{2}$ in the system forming $\mathrm{H}_{2} \mathrm{SO}_{4}$ is the time starting when a unit volume of the sample flow passes the position of the first injector pairs until it reaches the end of the atmospheric pressure ionization region, i.e., the $80 \mu \mathrm{m}$ aperture (see Fig. 1). That time in our system corresponds to $0.45 \mathrm{~s}$, or approximately half a second, which is about 6 times longer than $\tau_{\text {reac, } \mathrm{OH}}$. Therefore, the relative importance of $\mathrm{X}$ in comparison to the atmospheric $\mathrm{SO}_{2}$ oxidation efficiency of $\mathrm{OH}$ may have to be downscaled dependent on the properties of $\mathrm{X}$ and its potential formation and/or regeneration during the reaction time. Moreover, the atmospheric importance of $\mathrm{X}$ further depends on the $\mathrm{X}+\mathrm{SO}_{2}$ rate constant. This will be examined in detail in the following section.

Photolysis frequencies of ozone, $J\left(\mathrm{O}^{1} \mathrm{D}\right)$, and of nitrogen dioxide, $J\left(\mathrm{NO}_{2}\right)$, were measured starting in September 


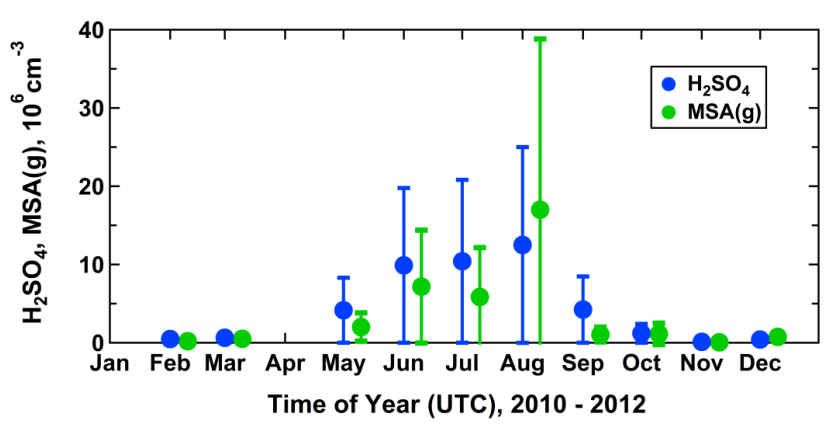

Figure 2. Midday (10:00-14:00 UTC) maximum $\mathrm{H}_{2} \mathrm{SO}_{4}$ and $\operatorname{MSA}(\mathrm{g})$ concentrations in marine air at Mace Head, averaged for each month (total measurement period: May 2010-August 2012). Vertical bars denote standard deviations.

2010 on top of a $10 \mathrm{~m}$ tower next to the laboratory building. Both were exchanged with recalibrated systems on a semiannual basis. Details of the measurement principles and performance of the radiometers have been given by Bohn et al. (2008). $\mathrm{SO}_{2}$ was measured in May-August 2011 with a Thermo Systems 43i instrument using a heated sample inlet Teflon tubing $\left(40^{\circ} \mathrm{C}\right)$ to avoid $\mathrm{SO}_{2}$ losses due to water condensate. Based on a cycle of $30 \mathrm{~min}$ signal and $30 \mathrm{~min}$ zero measurements (with an added active charcoal filter), we calculated a $2 \sigma$ detection limit of $25 \mathrm{pptv}$ for $1 \mathrm{~h}$ time integration.

\section{Results and discussion}

\subsection{Seasonal cycles and atmospheric lifetimes of $\mathrm{H}_{2} \mathrm{SO}_{4}$ and $\operatorname{MSA}(\mathrm{g})$}

Figure 2 shows the mean seasonal cycle of the daily maximum $\mathrm{H}_{2} \mathrm{SO}_{4}$ concentration in the marine sector at Mace Head, which typically occurred between 10:00 and 14:00 UTC, depending on cloud cover. In general, $\mathrm{H}_{2} \mathrm{SO}_{4}$ showed a clear diel variation closely correlated with the $\mathrm{OH}$ concentration (Fig. 3, top). The reason for this correlation was the relatively homogeneous mixing ratio of the major precursor, $\mathrm{SO}_{2}$, in the marine atmosphere, as shown for a 3-month period in Fig. 4 (top), and the relatively short lifetime of $\mathrm{H}_{2} \mathrm{SO}_{4}$ caused by uptake onto aerosol surfaces. This so-called condensational sink (CS) also showed low variability on most days (Fig. 4, bottom). The mean $\mathrm{SO}_{2}$ mixing ratio in the open ocean sector was $160( \pm 50)$ pptv during these summer months. The average atmospheric lifetime of $\mathrm{H}_{2} \mathrm{SO}_{4}$ with respect to CS was estimated from scanning mobility particle sizer (SMPS) and aerodynamic particle sizer (APS) measurements using the approach of Fuchs and Sutugin (1971) and of Seinfeld and Pandis (1998) to be on the order of $7 \mathrm{~min}$ assuming an accommodation coefficient of 1.0 (Kolb et al., 2010; Hanson, 2005; Boy et al., 2005), a diffusion coefficient for $\mathrm{H}_{2} \mathrm{SO}_{4}\left(2 \mathrm{H}_{2} \mathrm{O}\right)$ of $0.075 \mathrm{~atm} \mathrm{~cm}^{2} \mathrm{~s}^{-1}$ at

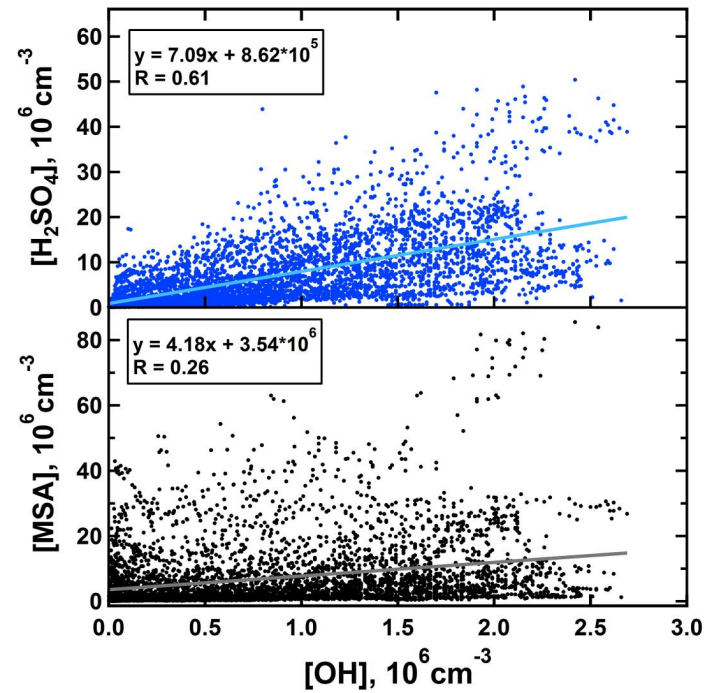

Figure 3. Correlation between $\mathrm{H}_{2} \mathrm{SO}_{4}$ and $\mathrm{OH}$ (top) and between $\operatorname{MSA}(\mathrm{g})$ and $\mathrm{OH}$ concentrations (bottom) in marine air for the period May-August 2011 (5 min integrated data; daytime: 08:00-20:00 UTC). To match the measured data in time $\mathrm{OH}$ concentrations were calculated based on concurrent $J\left(\mathrm{O}^{1} \mathrm{D}\right)$ data and the $J\left(\mathrm{O}^{1} \mathrm{D}\right)-\mathrm{OH}$ relationship for marine air previously established in Berresheim et al. (2013).

$75-85 \%$ relative humidity (Hanson, 2005), a mean free path of $105 \mathrm{~nm}$ for $\mathrm{H}_{2} \mathrm{SO}_{4}\left(2 \mathrm{H}_{2} \mathrm{O}\right)$ (corresponding to the Fuchs and Sutugin parameterization), and a hygroscopic growth factor of 1.7 (max. 2.0; $90 \% \mathrm{RH}$ vs. $\leq 40 \% \mathrm{RH}$ ) (Bialek et al., 2012). The variability of CS shown in Fig. 4 was mainly driven by particle counts, not relative humidity, which mostly ranged between 75 and $85 \%$. Overall, we estimate that CS values can be uncertain by at least a factor of 2 , mainly due to the uncertainties in the count rates of the SMPS and APS instruments and of the hygroscopic growth factor.

For Mace Head we assume that except perhaps in winter the predominant source for $\mathrm{H}_{2} \mathrm{SO}_{4}$ in the marine atmosphere is ultimately biogenic (Lin et al., 2012; Seguin et al., 2010), i.e., the emission and oxidation of dimethyl sulfide (DMS) by $\mathrm{OH}$ which yields - via further oxidation of intermediate compounds - the gaseous end products $\mathrm{H}_{2} \mathrm{SO}_{4}$, dimethyl sulfone $\left(\mathrm{CH}_{3} \mathrm{SO}_{2} \mathrm{CH}_{3}, \mathrm{DMSO}_{2}\right)$, and methane sulfonic acid $\left(\mathrm{CH}_{3} \mathrm{SO}_{3} \mathrm{H}, \mathrm{MSA}\right)$ (Berresheim et al., 1993a, 1995). As described in the previous section, the two acid compounds are detectable by SI/CIMS using the same instrumental setting as for the $\mathrm{OH}$ measurement. Corresponding seasonal cycles of aerosol MSA and non-sea-salt sulfate (nss-SO $\mathrm{S}_{4}$ ) have been measured at Mace Head using high-resolution timeof-flight aerosol mass spectrometry (HR-TOF-MS). Both aerosol compounds and their concentration ratio show a clear seasonal maximum in summer (Ovadnevaite et al., 2014). 


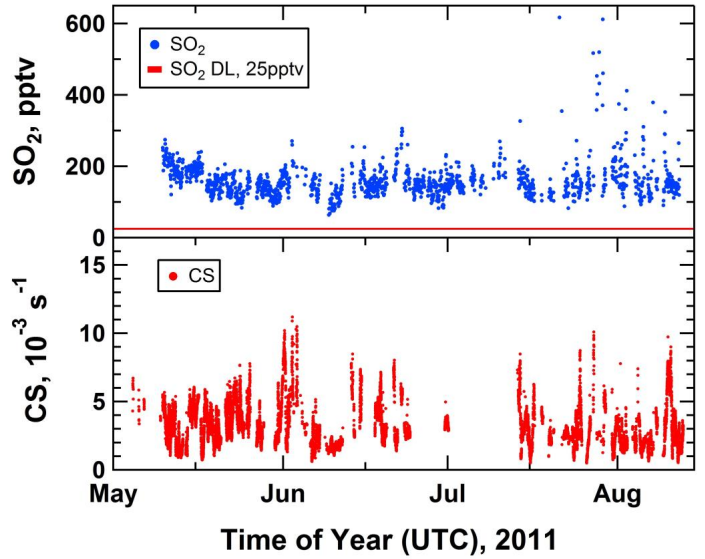

Figure 4. Top: $\mathrm{SO}_{2}$ mixing ratios ( $1 \mathrm{~h}$ signal integration) measured in marine air between May and August 2011 (average: 160 $( \pm 50)$ pptv; detection limit: 25 pptv, indicated by red line). Bottom: condensational sink (CS; 5 min integration) calculated for $\mathrm{H}_{2} \mathrm{SO}_{4}$ (see text).

The mean seasonal cycle of peak $\mathrm{MSA}(\mathrm{g})$ mixing ratios recorded during the same daily time slot as for $\mathrm{H}_{2} \mathrm{SO}_{4}$ and summarized as monthly means is also shown in Fig. 2. Similar to $\mathrm{H}_{2} \mathrm{SO}_{4}$ and the aerosol sulfur compounds, the highest gas-phase MSA(g) levels in the marine atmosphere were observed during the summer months, which corroborates the biogenic origin of $\mathrm{H}_{2} \mathrm{SO}_{4}$ measured in this sector. With the adoption of a sticking coefficient of 0.12 for the aerosol scavenging of MSA(g) (De Bruyn et al., 1994), we obtained an average atmospheric lifetime of approximately half an hour ( $25 \mathrm{~min}$ ) for this compound. As for $\mathrm{H}_{2} \mathrm{SO}_{4}$ this is somewhat shorter than previously estimated from measurements off the northwestern coast of the United States (Berresheim et al., 1993b), but still within the same order of magnitude. Ammann et al. (2013) questioned the earlier results obtained by De Bruyn et al. (1994) and Schweitzer et al. (1998) for the MSA(g) accommodation coefficient and suggested preferring a value close to 1 as reported in the most recent study by Hanson (2005). However, in our view, adopting a unity value would be in contradiction to common observations of a relatively slower decline of atmospheric MSA $(\mathrm{g})$ levels in comparison to $\mathrm{H}_{2} \mathrm{SO}_{4}$ in the late afternoon and evening hours, which has been well documented in previous field studies (e.g., Eisele and Tanner, 1993) and in our present study. Furthermore, as has already been shown in a previous campaign at Mace Head (Berresheim et al., 2002), ambient MSA(g) levels typically increased with decreasing relative humidity, including at nighttime. Both observations support that the vapor pressure of $\mathrm{MSA}(\mathrm{g})$ is significantly higher compared to $\mathrm{H}_{2} \mathrm{SO}_{4}$ (e.g., Kreidenweis and Seinfeld, 1988).
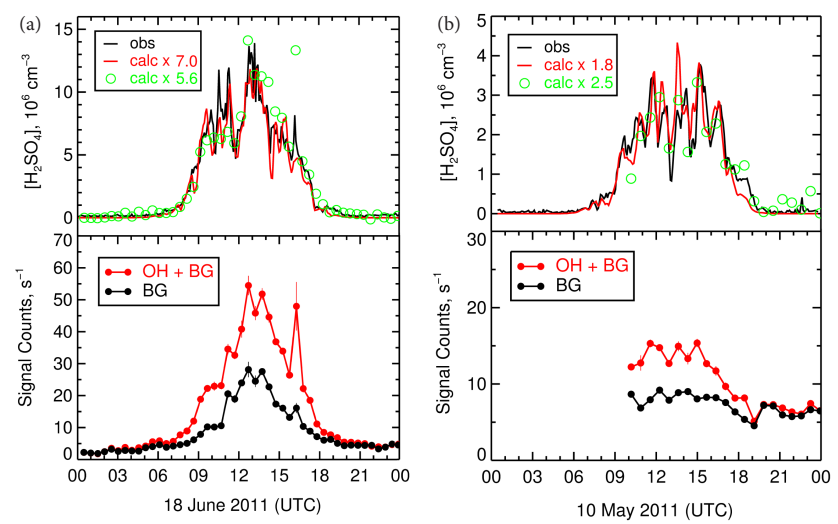

Figure 5. (a) Example of observed ambient $\mathrm{H}_{2} \mathrm{SO}_{4}$ concentration in comparison with $\mathrm{H}_{2} \mathrm{SO}_{4}$ mass balance values calculated from Eq. (1) for 18 June 2011. Air masses originated from polar regions between Greenland and Iceland, exhibiting strong biological activity in surface waters. As $\mathrm{OH}$ had only been measured for $5 \mathrm{~min}$ during each half-hour period, to obtain calculated $\mathrm{H}_{2} \mathrm{SO}_{4}$ for each of the corresponding measured $\mathrm{H}_{2} \mathrm{SO}_{4}$ values we used $J\left(\mathrm{O}^{1} \mathrm{D}\right)$ as a proxy for $\mathrm{OH}$ to fill the corresponding gaps based on the $\mathrm{OH}$ $J\left(\mathrm{O}^{1} \mathrm{D}\right)$ relation established for the marine sector (Berresheim et al., 2013) (continuous 5 min time resolution). Top: mean discrepancy factor of 7.0 between midday (10:00-14:00 UTC) observed and calculated $\left[\mathrm{H}_{2} \mathrm{SO}_{4}\right]$. Open symbols show calculated $\left[\mathrm{H}_{2} \mathrm{SO}_{4}\right]$ based on actual $\mathrm{OH}$ measurement signals (ratio: $5.6 \pm 1.2$ ). Bottom: signal counts obtained for $\mathrm{OH}$ measurement $(\mathrm{OH}$ plus background) and background mode only (cycle: $5 \mathrm{~min}$ during each $30 \mathrm{~min}$ period). (b) Example of relatively small discrepancy between measured and calculated $\mathrm{H}_{2} \mathrm{SO}_{4}$ based on Eq. (1) (ratio 1.8) and actual $\mathrm{OH}$ measurements (ratio $2.5 \pm 1.2$ ), respectively. With one exception, nighttime $\mathrm{OH}$ values were all below the detection limit. For further explanations see caption (a) and the main text. Air mass origin was mainly from the temperate North Atlantic in connection with anticyclonic conditions.

\section{2 $\quad \mathrm{H}_{2} \mathrm{SO}_{4}$ mass balance and missing $\mathrm{SO}_{2}$ oxidant in the marine atmosphere}

From 2 May to 12 August 2011, an intensive campaign was conducted at Mace Head that included measurements of $\mathrm{SO}_{2}$. The results allowed the calculation of $\mathrm{H}_{2} \mathrm{SO}_{4}$ concentrations based on its production by $\mathrm{SO}_{2}$ oxidation by $\mathrm{OH}$ and removal due to condensation on existing aerosol surface (CS, condensational sink rate) assuming steady state:

$\left[\mathrm{H}_{2} \mathrm{SO}_{4}\right]_{\mathrm{calc}}=\frac{k_{\mathrm{OH}}\left[\mathrm{SO}_{2}\right][\mathrm{OH}]}{\mathrm{CS}}$.

Comparison with measured $\mathrm{H}_{2} \mathrm{SO}_{4}$ concentrations showed a significant underestimation using Eq. (1), bearing in mind that the uncertainty in CS can be a factor of 2. For the available 38 days with concurrent $\mathrm{H}_{2} \mathrm{SO}_{4}, J\left(\mathrm{O}^{1} \mathrm{D}\right), \mathrm{CS}$, and $\mathrm{SO}_{2}$ observations, the mean ratio, i.e., $\left[\mathrm{H}_{2} \mathrm{SO}_{4}\right]_{\text {meas }} /\left[\mathrm{H}_{2} \mathrm{SO}_{4}\right]_{\text {calc }}$, was $4.7 \pm 2.4$ during the midday period, 10:00-14:00 UTC, taking calculated $\mathrm{OH}$ values from the relation $\mathrm{OH}-J\left(\mathrm{O}^{1} \mathrm{D}\right)$ (see below). The results for 26 days with direct $\mathrm{OH}$ observa- 
tions out of these 38 are $5.0 \pm 2.4$ based on the sparse direct $\mathrm{OH}$ observations and $4.8 \pm 2.5$ based on the denser $\mathrm{OH}$ values calculated from $J\left(\mathrm{O}^{1} \mathrm{D}\right)$. All of these results are considerably higher than the mean of 2.4 reported by Mauldin III et al. (2012) for a boreal forest site in Finland. An extreme example from 18 June 2011 is shown in Fig. 5a. On average, the measured $\mathrm{H}_{2} \mathrm{SO}_{4}$ concentrations on this day were a factor of 7 higher than the values calculated by Eq. (1) and the background signal shows a strong diel cycle in phase with that of $\mathrm{OH}$. Here we have filled the gaps in our $\mathrm{OH}$ measurements by using $J\left(\mathrm{O}^{1} \mathrm{D}\right)$ as proxy based on the $J\left(\mathrm{O}^{1} \mathrm{D}\right)-\mathrm{OH}$ relationship established in Berresheim et al. (2013) to obtain calculated $\mathrm{H}_{2} \mathrm{SO}_{4}$ for each of the measured $\mathrm{H}_{2} \mathrm{SO}_{4}$ values (continuous red line at the top of Fig. 5a). The results demonstrate the close tracking of the measured data and thus, the usefulness of this proxy application. In addition, the open symbols show the corresponding values based on the actual measured (5 min averaged) $\mathrm{OH}$ signals from that day (count rates shown in bottom of Fig. 5a). As can be seen, the latter procedure results in an average discrepancy factor of 5.6 \pm 1.2 , which agrees well with the above factor of 7.0 within given uncertainties.

Four-day NOAA HYSPLIT air mass back trajectories for 18 June 2011, (http://ready.arl.noaa.gov/HYSPLIT.php) in conjunction with MODIS satellite imagery (http://neo.sci. gsfc.nasa.gov) of chlorophyll pigments in surface seawater, pointed towards high biogenic sulfur (DMS) contributions to the advected air derived from phytoplankton blooms between Greenland and Iceland. On the other hand, no significant changes were observed in ambient $\mathrm{SO}_{2}$ levels on the same day. Even higher $\mathrm{H}_{2} \mathrm{SO}_{4}$ and also MSA(g) concentrations (both in the mid $-10^{7} \mathrm{~cm}^{-3}$ range) were measured on 11 June 2011, with similar air mass trajectories and $\mathrm{SO}_{2} \mathrm{lev-}$ els as those on 18 June, resulting in a measured/calculated $\mathrm{H}_{2} \mathrm{SO}_{4}$ ratio of 9. A notable difference between both days was the occurrence of low tide at noon on 18 June, whereas high tide prevailed at noon on 11 June, respectively.

A contrasting example is shown in Fig. 5b for 10 May 2011 , with a ratio of only 1.8 , which, in view of the overall uncertainties discussed earlier, suggests a nearly closed $\mathrm{H}_{2} \mathrm{SO}_{4}$ balance based on the $\mathrm{SO}_{2}+\mathrm{OH}$ pathway alone. Weather conditions on that day were strongly anticyclonic with no indication of major contributions from biologically active open ocean regions and with overall low solar insolation, i.e., lack of significant photochemistry. The $\mathrm{OH}$ background signal did not significantly vary during the day in contrast to the $\mathrm{OH}$ concentration itself, which despite low insolation still showed a pronounced diel cycle. However, as shown in Fig. 6, on the vast majority of marine sector days during the 2010 and 2011 measurement periods, both the background signal and the $\mathrm{OH}$ signal varied in tune with each other, which strongly suggests a photolytic source for the unknown compound(s) producing the $\mathrm{BG}$ signal.

Clearly a major source of $\mathrm{H}_{2} \mathrm{SO}_{4}$ in addition to $\mathrm{OH}$ oxidation of $\mathrm{SO}_{2}$ was missing in the balance calculation based

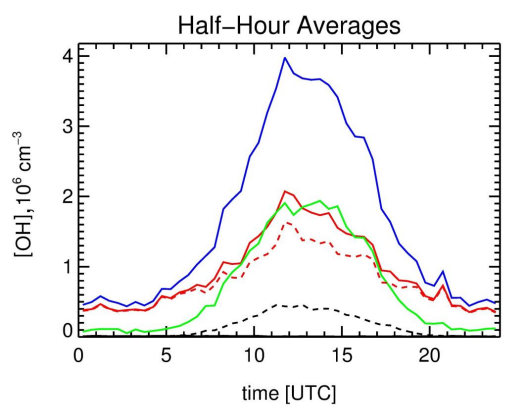

Figure 6. Mean half-hour values measured in marine air during the time period 2010-2011 calculated from the $\mathrm{OH}$ mode raw signal at $m / z, 99$ (blue line), total background mode raw signal at $m / z, 99$ (red line), $\mathrm{OH}$ mode signal minus background mode signal (green line: net signal counts corresponding to the ambient $\mathrm{OH}$ concentration), signal counts at $m / z 99$ due to ${ }^{34} \mathrm{~S}$ mass fraction of ambient $\mathrm{H}_{2} \mathrm{SO}_{4}$ (black dashed line: $\operatorname{signal}(m / z$ 97) $\cdot 0.044)$, and $\mathrm{OH}$ mode background signal with ${ }^{34} \mathrm{~S}$ fraction of ambient $\mathrm{H}_{2} \mathrm{SO}_{4}$ subtracted (red dashed line).

on Eq. (1). A similar discrepancy between measured and calculated $\mathrm{H}_{2} \mathrm{SO}_{4}$ concentrations in the coastal atmosphere of Mace Head was reported previously by Berresheim et al. (2002). They speculated that the missing source might be DMS oxidation with partial production of $\mathrm{SO}_{3}$ instead of $\mathrm{SO}_{2}$ as an intermediate, which then readily forms $\mathrm{H}_{2} \mathrm{SO}_{4}$ with water vapor (Lin and Chameides, 1993). This possibility would also agree with kinetic pathways hypothesized for the DMS + $\mathrm{OH}$ oxidation in which $\mathrm{CH}_{3} \mathrm{SO}_{2}$ and $\mathrm{CH}_{3} \mathrm{SO}_{3}$ are formed as intermediates, both of which decompose thermally to $\mathrm{SO}_{2}$ and $\mathrm{SO}_{3}$, respectively (Berresheim et al., 1995). Studies at an Antarctic coastal location with strong marine DMS emissions (Jefferson et al., 1998; Davis et al., 1998) reported similar inconsistencies between measured $\mathrm{H}_{2} \mathrm{SO}_{4}$ levels and $\mathrm{SO}_{2}$ mixing ratios required to close the mass balance based on $\mathrm{SO}_{2}+\mathrm{OH}$ as the only source, even when assuming a very low $\mathrm{H}_{2} \mathrm{SO}_{4}$ accommodation coefficient of 0.5 . Our results shown in Fig. 5a and b may be consistent with a significant contribution by marine biogenic DMS emissions to $\mathrm{H}_{2} \mathrm{SO}_{4}$ levels at Mace Head via intermediate production of a precursor other than $\mathrm{SO}_{2}$. Furthermore, this influence may even supersede potential regional contributions from emissions which are dependent on tidal cycles, as discussed earlier for the cases of 11 and 18 June 2011. However, current uncertainties in our knowledge of DMS oxidation chemistry prevent a quantitative assessment of this potential $\mathrm{H}_{2} \mathrm{SO}_{4}$ source.

Alternatively, biogenic emissions of, for example, organic halogens from the regional coastal environment during low tide may produce highly reactive atmospheric compounds that in addition to $\mathrm{OH}$ could play a significant role in atmospheric $\mathrm{H}_{2} \mathrm{SO}_{4}$ formation. Another class of compounds that have recently been suggested are stabilized Criegee intermediates (sCIs) which have been re-evaluated with re- 
spect to their potential oxidation of atmospheric $\mathrm{SO}_{2}$ by Liu et al. (2014), Stone et al. (2014), Welz et al. (2012), and Mauldin III et al. (2012). In the following two sections we investigate the potential importance of $\mathrm{SO}_{2}$ reactions with some halogen and $\mathrm{sCI}$ radicals as sources of $\mathrm{H}_{2} \mathrm{SO}_{4}$ in addition to the DMS $\rightarrow \mathrm{SO}_{3}$ and $\mathrm{SO}_{2}+\mathrm{OH}$ pathways in marine air at Mace Head. The nitrate radical, $\mathrm{NO}_{3}$, is not expected to be of any importance for nighttime $\mathrm{SO}_{2}$ oxidation at Mace Head, at least not in air from the marine sector (Berresheim et al., 2013).

\subsection{Electronic structure calculations on halogen oxide reactions with $\mathrm{SO}_{2}$}

Other candidates besides $\mathrm{OH}$ acting as $\mathrm{SO}_{2}$ oxidants might be halogen oxide radicals; however, to our knowledge respective rate constants are available in the literature only for the reactions of $\mathrm{IO}$ and $\mathrm{ClO}$ with $\mathrm{SO}_{2}$ (Larin et al., 2000; DeMore et al., 1997), which are 3 and 6 orders of magnitude smaller compared to $k_{\mathrm{SO}_{2}+\mathrm{OH}}$, respectively. We have made $a b$ initio transition state energy calculations for the reactions of $\mathrm{SO}_{2}$ with $\mathrm{ClO}, \mathrm{BrO}, \mathrm{IO}$, and $\mathrm{OIO}$ using quantum theory. The hybrid density functional/Hartree-Fock B3LYP method was employed from within the Gaussian 09 suite of programs (Frisch et al., 2009), combined with an appropriate basis set for I (Glukhovtsev et al., 1995) and the standard 6-311 $+\mathrm{g}(2 \mathrm{~d}, \mathrm{p})$ triple zeta basis sets for $\mathrm{Br}, \mathrm{Cl}, \mathrm{O}$, and $\mathrm{S}$. The geometries, rotational constants, vibrational frequencies, and relative energies of the transition states are listed in Table 1. Following geometry optimizations of the transition states for the reactions of $\mathrm{ClO}, \mathrm{BrO}, \mathrm{IO}$, and $\mathrm{OIO}$ with $\mathrm{SO}_{2}$, and the determination of their corresponding vibrational frequencies and (harmonic) zero-point energies, energies relative to the reactants were obtained. In the case of $\mathrm{BrO}$ and $\mathrm{ClO}+\mathrm{SO}_{2}$, more accurate transition state energies were computed at the CBS-QB3 level (Montgomery et al., 2000). At this level of theory, the expected uncertainty in the calculated transition state energies should be better than $0.07 \mathrm{eV}$ (Foresman and Frisch, 1996). Spin-orbit effects were ignored since these are present both in the reactant halogen oxide and the transition state. Figure 7 illustrates the transition state geometries for $\mathrm{ClO}, \mathrm{BrO}, \mathrm{IO}$, and $\mathrm{OIO}+\mathrm{SO}_{2}$.

Transition state theory (TST) calculations were then carried out using the calculated molecular parameters in Table 1. Although the reaction between $\mathrm{IO}$ and $\mathrm{SO}_{2}$ has a small barrier $\left(7.3 \mathrm{~kJ} \mathrm{~mol}^{-1}\right)$, the reaction has quite a tight transition state and the TST calculation yields $k(200-400 \mathrm{~K})=4.3 \times 10^{-14} \exp (-1150 / T) \mathrm{cm}^{3} \mathrm{~s}^{-1}$. The resulting value of $k(343 \mathrm{~K})=1.6 \times 10^{-15} \mathrm{~cm}^{3} \mathrm{~s}^{-1}$ is consistent with an experimental upper limit of $5.6 \times 10^{-15} \mathrm{~cm}^{3} \mathrm{~s}^{-1}$ determined at that temperature by Larin et al. (2000). At a marine boundary layer (MBL) temperature of $293 \mathrm{~K}$, the rate coefficient is only $8.5 \times 10^{-16} \mathrm{~cm}^{3} \mathrm{~s}^{-1}$. This reaction would have to compete with $\mathrm{OH}+\mathrm{SO}_{2}$, which has a rate coefficient of $k=9 \times 10^{-13} \mathrm{~cm}^{3} \mathrm{~s}^{-1}$. Although [IO] can be

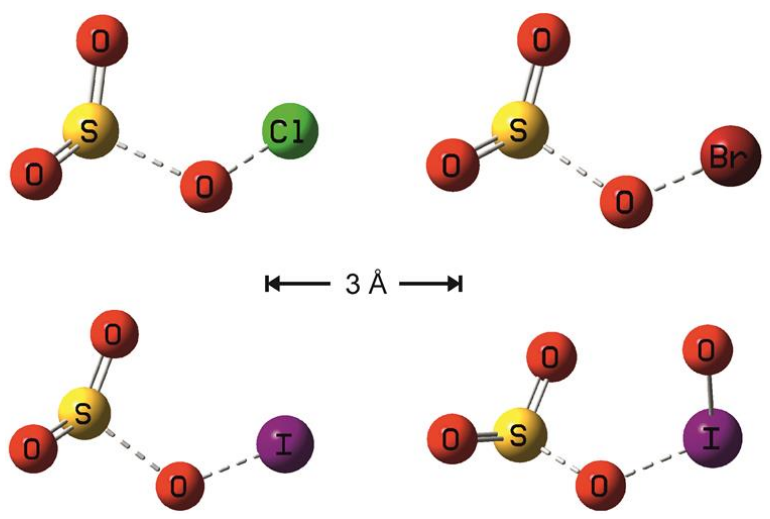

Figure 7. Transition state geometries for $\mathrm{ClO}, \mathrm{BrO}, \mathrm{IO}$, and $\mathrm{OIO}+\mathrm{SO}_{2}$.

around 30 times larger than $[\mathrm{OH}]$ at midday at Mace Head, the ratio of rate constants is $1 / 1050$, so the $\mathrm{OH}$ reaction is about 35 times faster. However, the estimated $\mathrm{SO}_{2}+\mathrm{IO}$ rate constant is large enough to allow for a fraction of $\mathrm{IO}$ to oxidize $\mathrm{SO}_{2}$ to $\mathrm{H}_{2} \mathrm{SO}_{4}$ inside the CIMS instrument and to contribute to the background signal (see Sect. 3.4).

During nighttime at Mace Head, OIO builds up to a mixing ratio of a few parts per trillion (Saiz-Lopez and Plane, 2004). However, the very large barrier for the $\mathrm{OIO}+\mathrm{SO}_{2}$ reaction $\left(50.1 \mathrm{~kJ} \mathrm{~mol}^{-1}\right)$ means that this reaction is negligibly slow: $\quad k(200-400 \mathrm{~K})=6.4 \times 10^{-13} \exp (-6400 / T) \mathrm{cm}^{3} \mathrm{~s}^{-1}$ and $k(293 \mathrm{~K})=2.2 \times 10^{-22} \mathrm{~cm}^{3} \mathrm{~s}^{-1}$.

$\mathrm{BrO}$ has been observed at a mixing ratio of several parts per trillion during the day at Mace Head (Saiz-Lopez et al., 2004). However, the reaction $\mathrm{BrO}+$ $\mathrm{SO}_{2}$ also has a significant barrier $\left(20.4 \mathrm{~kJ} \mathrm{~mol}^{-1}\right)$, and so the reaction is much too slow in the MBL: $k(200-400 \mathrm{~K})=5.8 \times 10^{-14} \exp (-2700 / T) \mathrm{cm}^{3} \mathrm{~s}^{-1}$ and $k(293 \mathrm{~K})=5.6 \times 10^{-18} \mathrm{~cm}^{3} \mathrm{~s}^{-1}$. Finally, the TST calculation for $\mathrm{ClO}+\mathrm{SO}_{2}$, which also has a significant barrier $\left(24.1 \mathrm{~kJ} \mathrm{~mol}^{-1}\right)$, yields $k=5.2 \times 10^{-14}$ $\exp (-3100 / T) \mathrm{cm}^{3} \mathrm{~s}^{-1}$. The theoretical rate coefficient at $298 \mathrm{~K}$ is therefore $1.5 \times 10^{-18} \mathrm{~cm}^{3} \mathrm{~s}^{-1}$, which is in accord with an experimental upper limit of $4 \times 10^{-18} \mathrm{~cm}^{3} \mathrm{~s}^{-1}$ at this temperature (DeMore et al., 1997). In summary, we conclude that none of the halogen oxides considered here exhibit sufficient turnover rates with $\mathrm{SO}_{2}$ in ambient air to account for the missing $\mathrm{H}_{2} \mathrm{SO}_{4}$ source.

\subsection{Could $X$ be a Criegee radical produced from ozonolysis?}

Previous measurements at Mace Head have shown clear diurnal cycles of light alkenes (including isoprene) with a strong dependence on solar flux (Broadgate et al., 2004; Lewis et al., 1999). Assuming that " $\mathrm{X}$ " is indeed a Criegee intermediate produced from ozonolysis of alkenes and reacting with $\mathrm{SO}_{2}$ both in the atmosphere and in the CIMS inlet system to 
Table 1. Molecular parameters and energies for transition state theory calculations (see text for theoretical methods). The symbol * indicates a transition state.

\begin{tabular}{|c|c|c|c|c|}
\hline Species & $\begin{array}{l}\text { Transition state } \\
\text { geometry }^{\mathrm{a}}\end{array}$ & $\begin{array}{l}\text { Rotational } \\
\text { constants } \\
(\mathrm{GHz})\end{array}$ & $\begin{array}{l}\text { Vibrational } \\
\text { frequencies }\left(\mathrm{cm}^{-1}\right)\end{array}$ & $\begin{array}{l}\text { Relative } \\
\text { energy } \\
\left(\mathrm{kJ} \mathrm{mol}^{-1}\right)\end{array}$ \\
\hline $\mathrm{ClO}$ & & 18.03 & 829 & - \\
\hline $\mathrm{SO}_{2}$ & & $\begin{array}{l}58.67,10.17, \\
8.667\end{array}$ & $508,1146,1334$ & - \\
\hline $\mathrm{ClO}-\mathrm{SO}_{2}^{*}$ & $\begin{array}{l}\mathrm{Cl}: 2.906,0.862,-0.283 \\
\mathrm{O}: 1.988,-0.503,-0.103 \\
\mathrm{~S}:-0.021,-0.255,-0.325 \\
\mathrm{O}:-0.353,1.084,0.116 \\
\mathrm{O}:-0.553,-1.414,0.357\end{array}$ & $\begin{array}{l}8.227, \quad 1.831, \\
1.540\end{array}$ & $\begin{array}{l}248 i, 73,135,270, \\
296,492,720,1113, \\
1303\end{array}$ & 24.1 \\
\hline $\mathrm{BrO}$ & & 12.50 & 713 & - \\
\hline $\mathrm{BrO}-\mathrm{SO}_{2}^{*}$ & $\begin{array}{l}\text { Br: }-0.048,0.360,0.367 \\
\text { O: } 0.235,-0.502,1.910 \\
\text { S: } 1.906,0.0189,3.011 \\
\text { O: } 2.914,0.483,2.075 \\
\text { O: } 2.140,-1.167,3.803\end{array}$ & $\begin{array}{l}8.138,1.128, \\
1.011\end{array}$ & $\begin{array}{l}239 i, 63,114,227, \\
280,494,625,1115, \\
1302\end{array}$ & 20.4 \\
\hline $\mathrm{IO}$ & & 9.844 & 649 & - \\
\hline $\mathrm{IO}-\mathrm{SO}_{2}^{*}$ & $\begin{array}{l}\text { I: } 1.387,0.0252,0.0250 \\
\text { O: }-0.292,-0.940,-0.130 \\
\text { S: }-2.056,0.068,0.307 \\
\text { O: }-1.803,1.417,0.167 \\
\text { O: }-2.984,-0.780,0.412\end{array}$ & $\begin{array}{l}8.050, \quad 0.875, \\
0.806\end{array}$ & $\begin{array}{l}258 i, 73,109,222, \\
292,495,613,1107, \\
1288\end{array}$ & 7.3 \\
\hline $\mathrm{OIO}$ & & $\begin{array}{l}18.31, \\
7.054,5.092\end{array}$ & $273,809,831$ & - \\
\hline $\mathrm{OIO}-\mathrm{SO}_{2}^{*}$ & $\begin{array}{l}\text { S: }-0.005,0.236,0.0738 \\
\text { O: } 0.210,0.766,1.416 \\
\text { O: } 1.111,-0.069,-0.803 \\
\text { I: }-1.644,3.069,0.096 \\
\text { O: }-0.961,1.427,-0.805 \\
\text { O: }-0.190,4.124,0.404\end{array}$ & $\begin{array}{l}4.572, \quad 0.871 \\
0.839\end{array}$ & $\begin{array}{l}304 i, 29,79,129 \\
202,261,417,495 \\
547,810,1064,1247\end{array}$ & 50.1 \\
\hline
\end{tabular}

\footnotetext{
a Atomic positions in Cartesian coordinates $(\AA)$;

$\mathrm{b}$ above the reactants, including zero-point energies.
}

produce additional $\mathrm{H}_{2} \mathrm{SO}_{4}$, we can estimate its relative contribution compared to the $\mathrm{SO}_{2}+\mathrm{OH}$ reaction as follows. In the following equations, the term $\mathrm{sCI}$ is used as a surrogate for sCI (stabilized Criegee intermediates) and CI (Criegee intermediates in general) species.

As already pointed out in the "Experimental" section, we have to account for additional formation of $[\mathrm{sCI}]_{\mathrm{cims}}$ from alkene $+\mathrm{O}_{3}$ reactions over the total available residence time of $0.45 \mathrm{~s}$ in the atmospheric pressure reaction and ionization region of the CIMS instrument (see Fig. 1). By continuous reaction with $\mathrm{SO}_{2}$ and ionization of the resulting $\mathrm{H}_{2}^{34} \mathrm{SO}_{4}$ molecules over the corresponding distance $(32 \mathrm{~cm})$ this leads to an accumulation of the $\mathrm{H}^{34} \mathrm{SO}_{4}^{-}$background signal at $m / z 99$ assuming the $\mathrm{sCI}+\mathrm{SO}_{2}$ oxidation to be instantaneous at the high $\mathrm{SO}_{2}$ concentration in the CIMS reactor tube. The enhancement factor, $\mathrm{EF}$, relative to the ambient air sCI concentration, $[\mathrm{sCI}]_{\mathrm{amb}}$, is

$\mathrm{EF}_{\mathrm{H}_{2}{ }^{34} \mathrm{SO}_{4}}=\frac{[\mathrm{sCI}]_{\mathrm{amb}}+\int_{0}^{\mathrm{t}_{\text {res }}} \operatorname{Prod}(\mathrm{sCI}) \cdot d t}{[\mathrm{sCl}]_{\mathrm{amb}}}=1+\frac{\mathrm{t}_{\mathrm{res}}}{\tau_{\mathrm{sCl}, \mathrm{amb}}}$.

This result is the consequence of the fact that both types of sCIs, namely sCIs present in ambient air $\left([\mathrm{sCI}]_{\mathrm{amb}}=\operatorname{Prod}(\mathrm{sCI}) \times \tau_{\mathrm{sCI}, \mathrm{amb}}\right)$ and sCIs produced inside the CIMS inlet, are immediately converted to $\mathrm{H}_{2}^{34} \mathrm{SO}_{4}$ by added ${ }^{34} \mathrm{SO}_{2}$ in the CIMS inlet system. With the assumption of a lifetime with respect to unimolecular decomposition of $0.2 \mathrm{~s}$ for sCI compounds resulting from ozonolysis of the monoterpenes $\alpha$-pinene and limonene (Mauldin 
III et al., 2012, Supplement) and the dominant ambient reaction of sCIs with water $\left(k_{\mathrm{H}_{2} \mathrm{O}+\mathrm{sCI}}=1.4 \times 10^{-17} \mathrm{~cm}^{3} \mathrm{~s}^{-1}\right.$ (MCM 3.2, http://mcm.leeds.ac.uk/MCM/; Saunders et al., 2003; Jenkin et al., 2003), $\left[\mathrm{H}_{2} \mathrm{O}\right]=3.1 \times 10^{17} \mathrm{~cm}^{-3}$ representing Mace Head conditions of $T=14^{\circ} \mathrm{C}, 75 \%$ relative humidity), the ambient lifetime of such stabilized Criegee intermediates is estimated to be $0.1 \mathrm{~s}$. As already mentioned, approximately $1 \%$ of the $\mathrm{H}_{2} \mathrm{SO}_{4}$ is ionized in the CIMS ionization region. Therefore, the production of sCIs in this region indeed yields $\mathrm{H}_{2} \mathrm{SO}_{4}$ via reaction with $\mathrm{SO}_{2}$, of which, however, only $0.5 \%$ is ionized on average as this process acts linearly. Consequently, we have to modify Eq. (2) to take into account the reduced ionization probability for $\mathrm{H}_{2} \mathrm{SO}_{4}$ produced in the ionization region:

$\mathrm{EF}_{\mathrm{H}^{34} \mathrm{SO}_{4}^{-}}=1+\frac{t_{\text {reac }}}{\tau_{\mathrm{sCI}, \mathrm{amb}}}+0.5 \cdot \frac{t_{\text {ion }}}{\tau_{\mathrm{sCl}, \mathrm{amb}}}$,

with $t_{\text {res }}=450 \mathrm{~ms}, \quad t_{\text {reac }}=115 \mathrm{~ms}, \quad t_{\text {ion }}=335 \mathrm{~ms}$, and $\tau_{\text {sCI,amb }}^{-1}=1 / 0.2 \mathrm{~s}+4.3 \mathrm{~s}^{-1}=9.3 \mathrm{~s}^{-1}$. This formalism is identical to that derived for a similar instrument by Berndt et al. (2012) (chemical ionization time-of-flight mass spectrometer with atmospheric pressure inlet: CI-APi-TOF-MS). Thus, from Eq. (3) it follows that ${ }^{34} \mathrm{SO}_{2}$ oxidation by sCIs contributes a background signal which represents an enhancement of the ambient sCI concentration by a factor $\mathrm{EF}=3.6$. Therefore, if $\mathrm{X}$ is indeed an $\mathrm{sCI}$ compound (of the kind considered here), the measurement signal resulting from sCIs would have to be weighted by $1: 3.6$ with respect to the $\mathrm{OH}$ signal to obtain the corresponding ambient air $[\mathrm{sCI}]$ concentration.

$[\mathrm{sCI}]_{\mathrm{amb}}=\frac{1}{\mathrm{EF}_{\mathrm{H}^{34} \mathrm{SO}_{4}^{-}}} \cdot \frac{\mathrm{BG}_{\mathrm{Sig}}}{\mathrm{OH}_{\mathrm{Sig}}} \cdot[\mathrm{OH}]_{\mathrm{amb}}$

To compare both compounds with respect to their oxidation efficiency towards $\mathrm{SO}_{2}$, the corresponding rate constants must be factored in as well, i.e., $k_{\mathrm{SCI}}+\mathrm{SO}_{2} / k_{\mathrm{OH}}+\mathrm{SO}_{2}$ $=6 \times 10^{-13} \mathrm{~cm}^{3} \mathrm{~s}^{-1} / 9 \times 10^{-13} \mathrm{~cm}^{3} \mathrm{~s}^{-1}=0.67$, with $k_{\mathrm{OH}+\mathrm{SO}_{2}}(298 \mathrm{~K})=9 \times 10^{-13} \mathrm{~cm}^{3} \mathrm{~s}^{-1}$ taken from Atkinson et al. (2004) and $k_{\mathrm{SCI}}+\mathrm{SO}_{2}$ adopted for the monoterpene derived $\mathrm{sCI}+\mathrm{SO}_{2}$ reaction as reported by Mauldin III et al. (2012).

This means that the relative oxidation efficiency (ROE) of those ozonolytically generated sCI compounds would be only on the order of $20 \%$ compared to that of $\mathrm{OH}$ with respect to $\mathrm{SO}_{2}$ oxidation, assuming that the CIMS background signal is equal to the $\mathrm{OH}$ signal as observed on average in the ambient air measurements at Mace Head (see Fig. 6).

$$
\begin{aligned}
\mathrm{ROE} & =\frac{k_{\mathrm{SCI}+\mathrm{SO}_{2}} \cdot[\mathrm{sCI}]_{\mathrm{amb}} \cdot\left[\mathrm{SO}_{2}\right]_{\mathrm{amb}}}{k_{\mathrm{OH}+\mathrm{SO}_{2}} \cdot[\mathrm{OH}]_{\mathrm{amb}} \cdot\left[\mathrm{SO}_{2}\right]_{\mathrm{amb}}} \\
& =\frac{1}{\mathrm{EF}_{\mathrm{H}^{34} \mathrm{SO}_{4}^{-}}} \cdot \frac{\mathrm{BG}_{\mathrm{Sig}}}{\mathrm{OH}_{\mathrm{Sig}}} \cdot \frac{k_{\mathrm{SCI}+\mathrm{SO}_{2}}}{k_{\mathrm{OH}+\mathrm{SO}_{2}}}
\end{aligned}
$$

These calculations depend strongly on the kinetic parameters for the corresponding $\mathrm{sCI}$ reactions. In this work we have adopted rate constants published by Mauldin III et al. (2012) and Berndt et al. (2012) for relatively large stabilized Criegee intermediates produced from ozonolysis of monoterpenes. However, other studies of smaller Criegee intermediates with low internal energies $\left(\mathrm{CH}_{2} \mathrm{OO}\right.$ by Stone et al. (2014), Berndt et al. (2014), and Welz et al. (2012); $\mathrm{CH}_{3} \mathrm{CHOO}$ by Taatjes et al.(2013)) suggest much faster reactions of these CI species with both $\mathrm{SO}_{2}$ and $\mathrm{H}_{2} \mathrm{O}$, respectively. They are produced from both ozonolysis of alkenes and from photolysis of, for example, $\mathrm{CH}_{2} \mathrm{I}_{2}$. Furthermore, laboratory studies by Fittschen et al. (2014) and Bossolasco et al. (2014) suggest that $\mathrm{CH}_{2} \mathrm{OO}$ could also be produced in the photochemical degradation of methane via the reaction of methyl peroxy radicals, $\mathrm{CH}_{3} \mathrm{O}_{2}$, with $\mathrm{OH}$. For a sensitivity test of the production pathway ozonolysis we neglect the fact that, for the conditions in the CIMS inlet, only approximately $80 \%$ of these CI would react with the added ${ }^{34} \mathrm{SO}_{2}$. The results are shown in Table 2.

We find that the oxidation efficiency of sCIs - if formed via ozonolysis - compared to $\mathrm{OH}$ would not be significant, based on the condition of equal CIMS background and $\mathrm{OH}$ signal counts. The relatively small difference between the estimates for such different species is a consequence of the fact that both reaction parameters (for $\mathrm{SCI}+\mathrm{SO}_{2}$ and $\mathrm{sCI}+\mathrm{H}_{2} \mathrm{O}$ ) are faster for the small Criegee intermediates. The effect of a faster reaction of sCIs with $\mathrm{SO}_{2}$ is almost exactly canceled out by the faster reactions with $\mathrm{H}_{2} \mathrm{O}$. A special case is $\mathrm{CH}_{2} \mathrm{OO}$, for which there is a debate regarding its reaction rate with water. Berndt et al. (2014) state that $\mathrm{CH}_{2} \mathrm{OO}$ reacts fast with $\mathrm{H}_{2} \mathrm{O}$ dimers, which was not accounted for in previous studies, but would dominate the fate of $\mathrm{CH}_{2} \mathrm{OO}$ in ambient air at Mace Head. But they could not explain the big difference to the small effects of water vapor on the $\mathrm{CH}_{2} \mathrm{OO}$ decay as deduced by Stone et al. (2014), who published a slow reaction constant for $\mathrm{CI}+\mathrm{H}_{2} \mathrm{O}$. In any case, ROE for $\mathrm{CH}_{2} \mathrm{OO}$ for average conditions at Mace Head is calculated to be small taking both sets of parameters from these two publications separately.

For these reasons, if the $\mathrm{X}$ oxidant(s) generating the $\mathrm{BG}$ signal of the CIMS instrument were one of the Criegee intermediates shown in Table 2 and were produced ozonolytically, the relative oxidation efficiencies for $\mathrm{SO}_{2}$ by these Criegee intermediates compared to $\mathrm{OH}$ for average conditions at Mace Head would be estimated to be small, increasing the calculated $\mathrm{H}_{2} \mathrm{SO}_{4}$ concentration based on the $\mathrm{SO}_{2}+\mathrm{OH}$ source alone by only $5-30 \%$. This is still a major shortfall with respect to the average factor of 4.7 required to match the observed ambient air $\mathrm{H}_{2} \mathrm{SO}_{4}$ concentration.

On the other hand, if the different Criegee intermediates shown in Table 2 were produced either photolytically or by reaction of a precursor with $\mathrm{OH}$, the corresponding enhancement factors EF would be 1 (no further production in the CIMS inlet) and the corresponding ROEs would be larger than 10, e.g., for $\mathrm{CH}_{2} \mathrm{OO}$ and $\mathrm{CH}_{3} \mathrm{CHOO}$. Taking the CIMS background signal as an upper limit for the estimate of their 
Table 2. Details of the calculation of the relative oxidation efficiency (ROE, see Eq. 5) for specific Criegee intermediates assuming ozonolysis of alkenes as their only source of formation for average ambient conditions at Mace Head $\left(14^{\circ} \mathrm{C}, 75 \% \mathrm{RH}, \mathrm{BG}_{\mathrm{sig}} / \mathrm{OH}_{\mathrm{sig}}=1\right)$.

\begin{tabular}{|c|c|c|c|c|c|}
\hline & $\mathrm{CH}_{2} \mathrm{OO}$ & anti- $\mathrm{CH}_{3} \mathrm{CHOO}$ & syni- $\mathrm{CH}_{3} \mathrm{CHOO}$ & $\alpha$-pinene & Limonene \\
\hline$k\left(\mathrm{sCI}+\mathrm{SO}_{2}\right)\left[\mathrm{cm}^{3} \mathrm{~s}^{-1}\right]$ & $3.9 \times 10^{-11 \mathrm{a}}$ & $6.7 \times 10^{-11 b}$ & $2.4 \times 10^{-11 b}$ & $5.9 \times 10^{-13 c}$ & $7.7 \times 10^{-13 c}$ \\
\hline$k\left(\mathrm{sCI}+\mathrm{H}_{2} \mathrm{O}\right)\left[\mathrm{cm}^{3} \mathrm{~s}^{-1}\right]$ & $<9 \times 10^{-17 d}$ & $1 \times 10^{-14 b}$ & $<4 \times 10^{-15 b}$ & $1.4 \times 10^{-17 \mathrm{e}}$ & $1.4 \times 10^{-17 \mathrm{e}}$ \\
\hline$\tau^{-1}$ (unimolecular) $\left[\mathrm{s}^{-1}\right]$ & $\begin{array}{l}500^{\mathrm{a}} \\
<100^{\mathrm{f}}\end{array}$ & $<250^{\mathrm{b}}$ & $<250^{\mathrm{b}}$ & $5^{\mathrm{c}}$ & $5^{c}$ \\
\hline$\tau^{-1}(8 \mathrm{ppm} \mathrm{SO} 2)\left[\mathrm{s}^{-1}\right]$ & 7800 & 13400 & 4800 & 118 & 154 \\
\hline$\tau^{-1}$ (ambient $\left.\mathrm{H}_{2} \mathrm{O}\right)\left[\mathrm{s}^{-1}\right]$ & $\begin{array}{l}27^{\mathrm{d}} \\
(2840)^{\mathrm{f}}\end{array}$ & 3000 & 1200 & 4.2 & 4.2 \\
\hline $\mathrm{EF}$ (Eq. 3) & 150 & 919 & 411 & 3.6 & 3.6 \\
\hline$k\left(\mathrm{sCI}+\mathrm{SO}_{2}\right) / k\left(\mathrm{OH}+\mathrm{SO}_{2}\right)$ & 43.3 & 74.4 & 26.7 & 0.66 & 0.86 \\
\hline ROE (Eq. 5) & $\begin{array}{l}0.29 \\
(0.05)^{\mathrm{f}}\end{array}$ & $0.09-0.08^{\mathrm{g}}$ & $0.08-0.06^{\mathrm{g}}$ & 0.18 & 0.24 \\
\hline $\begin{array}{l}\text { Fraction of sCIs reacting with }{ }^{34} \mathrm{SO}_{2} \text { in } \\
\text { the CIMS inlet }\end{array}$ & 0.94 & 0.80 & 0.77 & 0.93 & 0.94 \\
\hline $\begin{array}{l}\text { Welz et al. (2012), } \\
\text { Taatjes et al. (2013), } \\
\text { Mauldin III et al. (2012), } \\
\text { done at al. (2014), } \\
\text { MCM 3.2, } \\
\text { Merndt et al. (2014), } \\
\text { g range reflecting unimolecular decomposition rates 0-2 }\end{array}$ & & & & & \\
\hline
\end{tabular}

oxidation efficiency for $\mathrm{SO}_{2}$, it cannot be excluded that these small Criegee intermediates significantly influence the ambient $\mathrm{H}_{2} \mathrm{SO}_{4}$ budget at Mace Head. However, given the short atmospheric lifetime of these species, we doubt that sufficiently large steady-state concentrations are realistic.

The consequence for the ambient $\mathrm{H}_{2} \mathrm{SO}_{4}$ budget at Mace Head is complex. Either (1) very different ozonolytically produced Criegee intermediates than those studied so far, (2) photolytically produced Criegee intermediates, (3) Criegee intermediates produced via reactions of $\mathrm{OH}$, (4) an entirely different kind of oxidant for $\mathrm{SO}_{2}$, or (5) a production process converting a sulfur compound other than $\mathrm{SO}_{2}$ might be still missing in our present account of the $\mathrm{H}_{2} \mathrm{SO}_{4}$ concentration in the coastal marine atmosphere.

Figure $8 \mathrm{a}$ and $\mathrm{b}$ show two out of a few examples of observations we made during the May-August 2011 period which were not obscured by the midday primary $\mathrm{OH}$ production period in relation to coastal aerosol nucleation events during which $\mathrm{OH}$ and also both $\mathrm{H}_{2} \mathrm{SO}_{4}$ and $\mathrm{MSA}(\mathrm{g})$ concentrations increased significantly in conjunction with a major increase in the background signal counts for the X oxidant(s). On 13 May 2011 (Fig. 8a) the first low tide was centered at about 07:00 UTC. Note that no detectable aerosol nucleation ( $>3 \mathrm{~nm}$ diameter) occurred at this time, as insolation was still low; however, some spikes in both $\mathrm{OH}$ concentration and the BG signal were already visible. A significant nu- cleation event occurred during the second low tide between 18:00 and 21:00 UTC with somewhat enhanced $\mathrm{H}_{2} \mathrm{SO}_{4}$ and $\mathrm{MSA}(\mathrm{g})$ concentrations. Both the $\mathrm{OH}$ concentration and the $\mathrm{BG}$ signal again increased as well.

On the next day, 14 May 2011 (Fig. 8b), these effects are even more pronounced, with the tide shifted by about +45 min and two major nucleation events clearly detectable. The peak of the morning event at about 08:00 UTC coincided with a major production of both $\mathrm{OH}$ and the $\mathrm{X}$ compound (BG signal). In contrast to the preceding day, the evening event showed relatively minor $\mathrm{OH}$ and $\mathrm{X}$ production due to the tidal shift.

A recent successful $\mathrm{H}_{2} \mathrm{SO}_{4}$ intercomparison experiment at Mace Head (M. Sipilä and S. Richters, personal communication, 2013) between the CIMS instrument and a CIAPi-TOF-MS instrument has confirmed that the CIMS indeed measures only the concentration of gaseous "free" (monomeric) $\mathrm{H}_{2} \mathrm{SO}_{4}$ during nucleation events. With the rapid transition from monomers to multimer clusters in which $\mathrm{H}_{2} \mathrm{SO}_{4}$ becomes tied up (confined) and no longer broken down to the $\mathrm{HSO}_{4}^{-}$core ions in the CIMS collision dissociation chamber (Fig. 1), a net decrease in ambient $\mathrm{H}_{2} \mathrm{SO}_{4}$ concentrations may therefore be expected. However, as shown in the nucleation events in Fig. 8a and b, (monomer) $\mathrm{H}_{2} \mathrm{SO}_{4}$ levels even increased after a certain lag time following the onset of the event. We interpret our ob- 

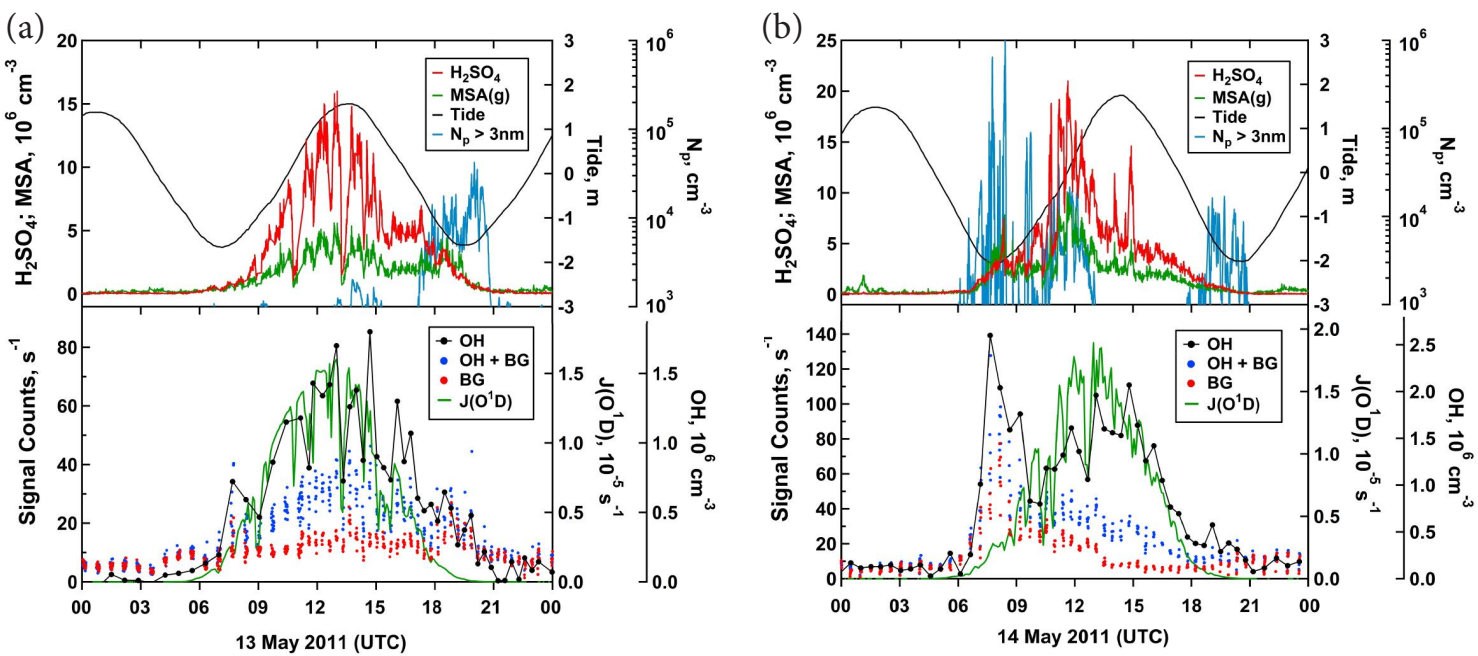

Figure 8. (a) Example observation showing relationships between aerosol nucleation events at low tide, OH concentrations, and OH background (BG) signal (due to X compound). Top: $\mathrm{H}_{2} \mathrm{SO}_{4}$ and $\mathrm{MSA}(\mathrm{g})$ concentrations ( $30 \mathrm{~s}$ integration), tidal height, and total particle number concentration $N_{\mathrm{p}}>3 \mathrm{~nm}$ diameter (30 s integration) measured with a condensation particle counter (CPC; TSI 3025). Bottom: OH concentrations ( $5 \mathrm{~min}$; black dots), count rates for $\mathrm{OH}+\mathrm{BG}$ and $\mathrm{BG}$ only (non-OH) signals $(30 \mathrm{~s})$, and ozone photolysis frequency $\left(J\left(\mathrm{O}^{1} \mathrm{D}\right)\right.$ ). (b) Example of increased $\mathrm{OH}$ concentrations and $\mathrm{OH}$ background signal (BG) during two aerosol nucleation events at low tide under marine sector conditions. Symbols as in (a).

servations as strong formation of $\mathrm{X}$ oxidant(s) (e.g., $\mathrm{CH}_{2} \mathrm{OO}$ from photolysis of $\mathrm{CH}_{2} \mathrm{I}_{2}$; Welz et al., 2012) or $\mathrm{OH}$ (perhaps via thermal decomposition of sCIs; Berndt et al., 2012, 2014; Kroll et al., 2001) followed by rapid oxidation of DMS and $\mathrm{SO}_{2}$ to form the products $\mathrm{H}_{2} \mathrm{SO}_{4}$ and $\mathrm{MSA}(\mathrm{g})$. Such coastal nucleation events have previously been shown to be induced by photolysis and photooxidation of marine iodine compounds emitted mainly from exposed seaweed during low tide (O'Dowd et al., 2002). Considering again the $\mathrm{IO}+\mathrm{SO}_{2}$ reaction and adopting a rate constant of $k\left(\mathrm{IO}+\mathrm{SO}_{2}\right)=8.5 \times 10^{-16} \mathrm{~cm}^{3} \mathrm{~s}^{-1}$ (Sect. 3.3), we calculate that approximately $8 \%$ of atmospheric IO is converting ${ }^{34} \mathrm{SO}_{2}$ to $\mathrm{H}_{2}^{34} \mathrm{SO}_{4}$ in the CIMS inlet system, based on a ${ }^{34} \mathrm{SO}_{2}$ mixing ratio of $8 \mathrm{ppmv}$ and a total $\mathrm{IO}$ residence time of $0.45 \mathrm{~s}$. Also, it is assumed that IO does not react with propane. Based on Eq. (3), the corresponding yield for $\mathrm{H}^{34} \mathrm{SO}_{4}^{-}$would be reduced from 8 to $5 \%$. With this estimate, an upper limit for the atmospheric IO mixing ratio can be derived from the corresponding CIMS background signal. We estimate ambient IO levels to be, on average, less than 1.3 pptv at noontime (Fig. 6) and less than 5 pptv at the maximum of the nucleation event shown in Fig. 8a and b. This is consistent with previous measurements of IO at Mace Head which showed maximum levels up to 5 pptv (Saiz-Lopez et al., 2006; Alicke et al., 1999). However, other measurements taken over "hot spots" of exposed seaweed beds have shown IO peak values of up to 50 pptv (Commane et al., 2011). Thus, it can be concluded that the observed background signal could be explained by the presence of IO that would nevertheless not contribute to atmospheric $\mathrm{SO}_{2}$ oxidation be- cause of a too small $\mathrm{IO}+\mathrm{SO}_{2}$ rate constant. Future studies are required in order to systematically characterize remaining uncertainties in the CIMS and CS measurements and to verify a possible link between the unknown oxidant(s), the CIMS background, and the iodine cycle in the marine atmosphere.

\section{Conclusions}

We observed a persistent but relatively low $\mathrm{H}_{2} \mathrm{SO}_{4}$ concentration at nighttime (on the order of a few $10^{5} \mathrm{~cm}^{-3}$ ). Also, on some occasions, short spikes were observed at nighttime in the $\mathrm{H}_{2} \mathrm{SO}_{4}$ signal during low tide, which might suggest short-term emissions of reactive hydrocarbons capable of forming Criegee intermediates and $\mathrm{OH}$ in reactions with ozone, both capable of oxidizing $\mathrm{SO}_{2}$. We assume that such processes also happen during daytime but are superimposed by the formation of another major oxidant which shows a similar diurnal pattern like $\mathrm{OH}$. A detailed analysis of the atmospheric $\mathrm{H}_{2} \mathrm{SO}_{4}$ budget at Mace Head revealed that a dominant oxidant for the production of $\mathrm{H}_{2} \mathrm{SO}_{4}$ is missing, which, on average, would have to contribute 4.7 times more than the observed production from $\mathrm{OH}+\mathrm{SO}_{2}$. Whether this oxidant might be a Criegee intermediate with its production mainly determined by strong light-induced emissions of marine alkene species and/or atmospheric photolysis of iodine species remains an open question. However, we consider it unlikely that $\alpha$-pinene or limonene are present at significant levels in the marine atmosphere. In forest environments these compounds are also emitted at nighttime, result- 
ing in a quite different diurnal cycle of the CIMS background signal (Mauldin III et al., 2012) than we have observed in the coastal atmosphere. In the present work we have shown that the signal measured with the CIMS instrument during its background mode indeed provides evidence for the presence of one or more unknown oxidants for atmospheric $\mathrm{SO}_{2}$ in addition to $\mathrm{OH}$. However, as this $\mathrm{X}$ oxidant does not significantly react with propane in the CIMS system, the corresponding $\mathrm{X}$ signal must be corrected in some cases to account for additional production inside the CIMS inlet system before evaluating its oxidation efficiency towards $\mathrm{SO}_{2}$ in ambient air. For this reason, and also based on the currently available kinetic data for the $\mathrm{SO}_{2}$ oxidation by sCI compounds resulting from monoterpenes or from smaller alkenes, we conclude that at least Criegee intermediates produced via ozonolysis are unimportant in comparison with the $\mathrm{SO}_{2}+\mathrm{OH}$ oxidation in the marine atmosphere at Mace Head. It appears that Mauldin III et al. (2012) have not considered this correction, which reduces the proposed oxidation efficiency for $\mathrm{SO}_{2}$ of stabilized Criegee intermediates from ozonolysis of $\alpha$-pinene or limonene in forested environments as well. Theoretical calculations of the oxidation of $\mathrm{SO}_{2}$ by the halogen oxides $\mathrm{ClO}, \mathrm{BrO}, \mathrm{IO}$, or $\mathrm{OIO}$ show that those reactions are too slow to influence the atmospheric concentration of $\mathrm{H}_{2} \mathrm{SO}_{4}$. On the other hand, $\mathrm{CH}_{2} \mathrm{OO}$ formed via photolysis of $\mathrm{CH}_{2} \mathrm{I}_{2}$ appears to be a candidate to explain the observed increase in the CIMS background signal, especially during daytime aerosol nucleation events at low tide, and appears to have a significant impact on the ambient $\mathrm{H}_{2} \mathrm{SO}_{4}$ budget. In any case, more comprehensive measurements including alkenes, isoprene, and halogen compounds are needed in conjunction with laboratory kinetic studies to confirm the presence of oxidant species other than $\mathrm{OH}$ with significant contributions to the $\mathrm{H}_{2} \mathrm{SO}_{4}$ budget in the marine atmosphere. An additional source of $\mathrm{H}_{2} \mathrm{SO}_{4}$ not accounted for by the $\mathrm{SO}_{2}+(\mathrm{OH}$ or $\mathrm{X})$ pathway may be the formation of $\mathrm{SO}_{3}$ (instead of $\mathrm{SO}_{2}$ ) as an intermediate in the oxidation of DMS followed by rapid reaction with water vapor. To better evaluate the contribution from this potential source, further studies involving additional measurements of DMS are planned for future work in conjunction with what we have already attempted in the present study, i.e., analysis of air mass advection from biologically active oceanic regions using satellite remote sensing data.

Acknowledgements. We would like to thank J. McGrath, R. L. Mauldin III, and F. Eisele for helpful discussions. J. McGrath also helped with the measurements. Financial support for this work was provided by the Science Foundation Ireland (grant 09/RFP/GEO2176); EPA Ireland (grant 2007-INF-12-S5); the Higher Education Authority Programme for Research in Third Level Institutes - Cycle 4; and European Commission Framework Programme projects EUCAARI (036833-2), ACTRIS (262254), and EUSAAR.
This work is dedicated to Kurt and Jessica by H. Berresheim.

Edited by: P. Monks

\section{References}

Alicke, B., Hebestreit, K., Stutz, J., and Platt, U.: Iodine oxide in the marine boundary layer, Nature, 397, 572-573, 1999.

Ammann, M., Cox, R. A., Crowley, J. N., Jenkin, M. E., Mellouki, A., Rossi, M. J., Troe, J., and Wallington, T. J.: Evaluated kinetic and photochemical data for atmospheric chemistry: Volume VI - heterogeneous reactions with liquid substrates, Atmos. Chem. Phys., 13, 8045-8228, doi:10.5194/acp-13-8045-2013, 2013.

Atkinson, R., Baulch, D. L., Cox, R. A., Crowley, J. N., Hampson, R. F., Hynes, R. G., Jenkin, M. E., Rossi, M. J., and Troe, J.: Evaluated kinetic and photochemical data for atmospheric chemistry: Volume $\mathrm{I}-$ gas phase reactions of $\mathrm{O}_{\mathrm{x}}, \mathrm{HO}_{\mathrm{x}}, \mathrm{NO}_{\mathrm{x}}$ and $\mathrm{SO}_{\mathrm{x}}$ species, Atmos. Chem. Phys., 4, 1461-1738, doi:10.5194/acp-41461-2004, 2004.

Berndt, T., Jokinen, T., Mauldin III, R. L., Petäjä, T., Herrmann, H., Junninen, H., Paasonen, P., Worsnop, D. R., and Sipilä, M.: Gas-phase ozonolysis of selected olefins: the yield of stabilized Criegee intermediates and the reactivity toward $\mathrm{SO}_{2}$, J. Phys. Chem. Lett., 3, 2892-2896 and the supplement, 2012.

Berndt, T., Jokinen, T., Sipilä, M., Mauldin III, R. L., Herrmann, H., Stratmann, F., Junninen, H., and Kulmala, M.: $\mathrm{H}_{2} \mathrm{SO}_{4}$ formation from the gas-phase reaction of stabilized Criegee Intermediates with $\mathrm{SO}_{2}$ : Influence of water vapour content and temperature, Atmos. Environ., 89, 603-612, 2014.

Berresheim, H. and Jaeschke, W.: Study of metal aerosol systems as a sink for atmospheric $\mathrm{SO}_{2}$, J. Atmos. Chem., 4, 311-334, 1986.

Berresheim, H., Eisele, F. L., and Tanner, D. J.: Field studies of atmospheric DMS chemistry using selected ion chemical ionization mass spectrometry, in Dimethylsulfide: Oceans, Atmosphere and Climate, edited by: Restelli, G., and Angeletti, G., 239-242, Kluwer Academic Publishers, Dordrecht, 1993a.

Berresheim, H., Eisele, F. L., Tanner, D. J., Covert, D. S., McInnes, L., and Ramsey Bell, D. C.: Atmospheric sulfur chemistry and cloud condensation nuclei $(\mathrm{CCN})$ concentrations over the northeastern Pacific coast, J. Geophys. Res., 98, 12701-12711, 1993b.

Berresheim, H., Wine, P. H., and Davis, D. D.: Sulfur in the atmosphere, in Composition,Chemistry, and Climate of the Atmosphere, edited by: Singh, H. B., 251-307, Van Nostrand Reinhold, New York, 1995.

Berresheim, H., Elste, T., Plass-Dülmer, C., Eisele, F. L., and Tanner, D. J.: Chemical ionization mass spectrometer for long-term measurements of atmospheric $\mathrm{OH}$ and $\mathrm{H}_{2} \mathrm{SO}_{4}$, Int. J. Mass Spectrom., 202, 91-109, 2000.

Berresheim, H., Elste, T., Tremmel, H. G., Allen, A. G., Hansson, H.-C., Rosman, K., DalMaso, M., Mäkelä, J. M., Kulmala, M., and O'Dowd, C. D.: Gas-aerosol relationships of $\mathrm{H}_{2} \mathrm{SO}_{4}$, MSA, and $\mathrm{OH}$ : Observations in the coastal marine boundary layer at Mace Head, Ireland, J. Geophys. Res., 107, 8100, doi:10.1029/2000JD000229, 2002.

Berresheim, H., McGrath, J., Adam, M., Mauldin III, R. L., Bohn, B., and Rohrer, F.: Seasonal Measurements of $\mathrm{OH}, \mathrm{NO}_{\mathrm{x}}$, and $J\left(\mathrm{O}^{1} \mathrm{D}\right)$ at Mace Head, Ireland, Geophys. Res. Lett., 40, 1659-16632013. 
Bialek, J., Dall'Osto, M., Monahan, C., Beddows, D., and O’Dowd, C.: On the contribution of organics to the North East Atlantic aerosol number concentration, Environ. Res. Lett., 7, 044013, doi:10.1088/1748-9326/7/4/044013, 2012.

Bohn, B., Corlett, G. K., Gillmann, M., Sanghavi, S., Stange, G., Tensing, E., Vrekoussis, M., Bloss, W. J., Clapp, L. J., Kortner, M., Dorn, H.-P., Monks, P. S., Platt, U., Plass-Dülmer, C., Mihalopoulos, N., Heard, D. E., Clemitshaw, K. C., Meixner, F. X., Prevot, A. S. H., and Schmitt, R.: Photolysis frequency measurement techniques: results of a comparison within the ACCENT project, Atmos. Chem. Phys., 8, 5373-5391, doi:10.5194/acp-85373-2008, 2008.

Bossolasco, A., Faragó, E. P., Schoemaecker, C., and Fittschen, C.: Rate constant of the reaction between $\mathrm{CH}_{3} \mathrm{O}_{2}$ and $\mathrm{OH}$ radicals, Chem. Phys. Lett., 593, 7-13, 2014.

Boy, M., Kulmala, M., Ruuskanen, T. M., Pihlatie, M., Reissell, A., Aalto, P. P., Keronen, P., Dal Maso, M., Hellen, H., Hakola, H., Jansson, R., Hanke, M., and Arnold, F.: Sulphuric acid closure and contribution to nucleation mode particle growth, Atmos. Chem. Phys., 5, 863-878, doi:10.5194/acp-5-863-2005, 2005.

Boy, M., Mogensen, D., Smolander, S., Zhou, L., Nieminen, T., Paasonen, P., Plass-Dülmer, C., Sipilä, M., Petäjä, T., Mauldin, L., Berresheim, H., and Kulmala, M.: Oxidation of SO2 by stabilized Criegee intermediate $(\mathrm{sCI})$ radicals as a crucial source for atmospheric sulfuric acid concentrations, Atmos. Chem. Phys., 13, 3865-3879, doi:10.5194/acp-13-3865-2013, 2013.

Broadgate, W. J., Malin, G., Küpper F. C.,, Thompson, A., and Liss, P. S.: Isoprene and other non-methane hydrocarbons from seaweeds: a source of reactive hydrocarbons to the atmosphere, Marine Chem., 88, 61-73, 2004.

Calvert, J. G., Atkinson, R., Kerr, J. A., Madronich, S., Moortgat, G. K., Wallington, T. J., and Yarwood, G.: The mechanisms of atmospheric oxidation of the alkenes, Oxford University Press, New York, ISBN 0-19-513177-0, 560 pp., 2000.

Commane, R., Seitz, K., Bale, C. S. E., Bloss, W. J., Buxmann, J., Ingham, T., Platt, U., Pöhler, D., and Heard, D. E.: Iodine monoxide at a clean marine coastal site: observations of high frequency variations and inhomogeneous distributions, Atmos. Chem. Phys., 11, 6721-6733, doi:10.5194/acp-11-6721-2011, 2011.

Cox, R. A. and Penkett, S. A.: Oxidation of atmospheric $\mathrm{SO}_{2}$ by products of the ozone-olefin reaction, Nature, 230, 321-322, 1971.

Criegee, R.: Mechanism of ozonolysis, Angew. Chem.-Int. Edit. Engl., 14, 745-752, 1975.

Davis, D., Chen, G., Kasibhatla, P., Jefferson, A., Tanner, D., Eisele, F., Lenschow, D., Neff, W., and Berresheim, H.: DMS oxidation in the Antarctic marine boundary layer: Comparison of model simulations and field observations of DMS, DMSO, $\mathrm{DMSO}_{2}, \mathrm{H}_{2} \mathrm{SO}_{4}(\mathrm{~g}), \mathrm{MSA}(\mathrm{g})$, and MSA(p), J. Geophys. Res., 103, 1657-1678, 1998.

De Bruyn, W. J., Shorter, J. A., Davidovits, P., Worsnop, D. R., Zahniser, M. S., and Kolb, C. E.: Uptake of gas phase sulfur species methanesulfonic acid, dimethylsulfoxide, and dimethyl sulfone by aqueous surfaces, J. Geophys. Res., 99, 16927-16932, doi:10.1029/94JD00684, 1994.

DeMore, W. B., Sander, S. P., Golden, D. M., Hampson, R. F., Kurylo, M. J., Howard, C. J., Ravishankara, A. R., Kolb, C. E., and Molina, M. J.: Chemical kinetics and photochemical data for use in stratospheric modeling, evaluation number 12, JPL Publication 97-4, 1-266, 1997.

Eisele, F. and Tanner, D.: Measurement of the gas phase concentration of $\mathrm{H}_{2} \mathrm{SO}_{4}$ and methane sulfonic acid and estimates of $\mathrm{H}_{2} \mathrm{SO}_{4}$ production and loss in the atmosphere, J. Geophys. Res, 98, 9001-9010, 1993.

Eisele, F. L. and Berresheim, H.: High pressure chemical ionization flow reactor for realtime mass spectrometric detection of sulfur gases and unsaturated hydrocarbons in air, Anal. Chem., 64, 283-287, 1992.

Eisele, F. L. and Tanner, D. J.: Ion-assisted tropospheric OH measurements, J. Geophys. Res., 96, 9295-9308, 1991.

Fittschen, C., Whalley, L. K., and Heard, D. E.: The reaction of $\mathrm{CH}_{3} \mathrm{O}_{2}$ radicals with $\mathrm{OH}$ radicals: a neglected sink for $\mathrm{CH}_{3} \mathrm{O}_{2}$ in the remote atmosphere, Environ. Sci. Technol., 48, 7700-7701, 2014.

Foresman, J. B. and Frisch, A.: Exploring chemistry with electronic structure methods, Gaussian, Inc., Pittsburgh, 1-303, 1996.

Frisch, M. J., Trucks, G. W., Schlegel, H. B., Scuseria, G. E., Robb, M. A., Cheeseman, J. R., Scalmani, G., Barone, V., Mennucci, B., Petersson, G. A., Nakatsuji, H., Caricato, M., Li, X., Hratchian, H. P., Izmaylov, A. F., Bloino, J., Zheng, G., Sonnenberg, J. L., Hada, M., Ehara, M., Toyota, K., Fukuda, R., Hasegawa, J., Ishida, M., Nakajima, T., Honda, Y., Kitao, O., Nakai, H., Vreven, T., Montgomery Jr., J. A., Peralta, J. E., Ogliaro, F., Bearpark, M., Heyd, J. J., Brothers, E., Kudin, K. N., Staroverov, V. N., Kobayashi, R., Normand, J., Raghavachari, K., Rendell, A., Burant, J. C., Iyengar, S. S., Tomasi, J., Cossi, M., Rega, N., Millam, J. M., Klene, M., Knox, J. E., Cross, J. B., Bakken, V., Adamo, C., Jaramillo, J., Gomperts, R., Stratmann, R. E., Yazyev, O., Austin, A. J., Cammi, R., Pomelli, C., Ochterski, J. W., Martin, R. L., Morokuma, K., Zakrzewski, V. G., Voth, G. A., Salvador, P., Dannenberg, J. J., Dapprich, S., Daniels, A. D., Farkas, Ö., Foresman, J. B., Ortiz, J. V., Cioslowski, J., and Fox, D. J.: Gaussian 09, Revision A.1. Gaussian, Inc. 2009.

Fuchs, N. and Sutugin, A.: High-dispersed aerosol, in Topics in Current Aerosol Research, edited by: Hidy, G. and Brock, J., Pergamon, New York, 1-60, 1971.

Glukhovtsev, M. N., Pross, A., McGrath, M. P., and Radom, L.: Extension of Gaussian-2 (G2) theory to bromine- and iodinecontaining molecules: Use of effective core potentials, J. Chem. Phys., 103, 1878-1885, 1995.

Hanson, D. R.: Mass accommodation of $\mathrm{H}_{2} \mathrm{SO}_{4}$ and $\mathrm{CH}_{3} \mathrm{SO}_{3} \mathrm{H}$ on water-sulfuric acid solutions from $6 \%$ to $97 \% \mathrm{rH}$, J. Phys. Chem. A, 109, 6919-6927, 2005.

Harris, E., Sinha, B., van Pinxteren, D., Tilgner, A., Fomba, K. W., Schneider, J., Roth, A., Gnauk, T., Fahlbusch, B., Mertes, S., Lee, T., Collett, J., Foley, S., Borrmann, S., Hoppe, P., and Herrmann, H.: Enhanced role of transition metal ion catalysis during in-cloud oxidation of $\mathrm{SO}_{2}$, Science, 340, 727-730, 2013.

Heard, D. E. and Pilling, M. J.: Measurement of $\mathrm{OH}$ and $\mathrm{HO}_{2}$ in the troposphere, Chem. Rev., 103, 5163-5198, 2003.

Huey, G. L.: Measurement of trace atmospheric species by chemical ionization mass spectrometry: Speciation of reactive nitrogen and future directions, Mass Spectrom. Rev., 26, 166-184, 2007.

Jefferson, A., Tanner, D. J., Eisele, F. L., and Berresheim, H.: Sources and sinks of $\mathrm{H}_{2} \mathrm{SO}_{4}$ in the remote Antarctic marine boundary layer, J. Geophys. Res., 103, 1639-1645 1998. 
Jenkin, M. E., Saunders, S. M., Wagner, V., and Pilling, M. J.: Protocol for the development of the Master Chemical Mechanism, MCM v3 (Part B): tropospheric degradation of aromatic volatile organic compounds, Atmos. Chem. Phys., 3, 181-193, doi:10.5194/acp-3-181-2003, 2003.

Kolb, C. E., Cox, R. A., Abbatt, J. P. D., Ammann, M., Davis, E. J., Donaldson, D. J., Garrett, B. C., George, C., Griffiths, P. T., Hanson, D. R., Kulmala, M., McFiggans, G., Pöschl, U., Riipinen, I., Rossi, M. J., Rudich, Y., Wagner, P. E., Winkler, P. M., Worsnop, D. R., and O' Dowd, C. D.: An overview of current issues in the uptake of atmospheric trace gases by aerosols and clouds, Atmos. Chem. Phys., 10, 10561-10605, doi:10.5194/acp-10-10561-2010, 2010.

Kreidenweis, S. M. and Seinfeld, J. H.: Nucleation of sulfuric acid water and methanesulfonic acid-water solution particles: Implications for the atmospheric chemistry of organosulfur species, Atmos. Environ., 22, 283-296, 1988.

Kroll, J. H., Shailesh, R. S., Anderson, J. G., Demerjian, K. L., and Donahue, N. M.: Mechanism of $\mathrm{HO}_{\mathrm{x}}$ formation in the gas-phase ozone-alkene reaction. 2. Prompt versus thermal dissociation of carbonyl oxides to form OH, J. Phys. Chem. A, 105, 4446-4457, 2001.

Krouse, H. R. and Grinenko, V. A. (Eds.): Stable Isotopes: Natural and Anthropogenic Sulphur in the Environment, Scientific Committee on Problems of the Environment (SCOPE), vol. 43, J. Wiley \& Sons, Chichester, 1-440, 1991.

Larin, I. K., Messineva, N. A., Spasskii, A. I., Trofimova, E. M., and Turkin, L. E.: Measurement of the rate constants for the reactions of the $\mathrm{IO}^{\bullet}$ radical with sulfur-containing compounds $\mathrm{H}_{2} \mathrm{~S}$, $\left(\mathrm{CH}_{3}\right)_{2} \mathrm{~S}$, and $\mathrm{SO}_{2}$, J. Kinet. Catalys., 41, 437-443, 2000.

Lewis, A. C., McQuaid, J. B., Carslaw, N., and Pilling, M. J.: Diurnal cycles of short-lived tropospheric alkenes at a north Atlantic coastal site, Atmos. Environ., 33, 2417-2422, 1999.

Lin, C. T., Baker, A. R., Jickells, T. D., Kelly, S., and Lesworth, T.: An assessment of the significance of sulphate sources over the Atlantic Ocean based on sulphur isotope data, Atmos. Environ., 62, 615-621 2012.

Lin, X. and Chameides, W. L.: CCN formation from DMS oxidation without $\mathrm{SO}_{2}$ acting as an intermediate, Geophys. Res. Lett., 20, 579-582, 1993.

Liu, Y., Bayes, K. D., and Sander, S. P.: Measuring rate constants for reactions of the simplest Criegee intermediate $\left(\mathrm{CH}_{2} \mathrm{OO}\right)$ by monitoring the OH radical, J. Phys. Chem. A, 118, 741-747, 2014.

Mauldin III, R., Frost, G., Chen, G., Tanner, D., Prevot, A., Davis, D., and Eisele, F.: OH measurements during the First Aerosol Characterization Experiment (ACE 1): Observations and model comparisons, J. Geophys. Res., 103, 16713-16729, 1998.

Mauldin III, R. L., Berndt, T., Sipilä, M., Paasonen, P., Petäjä, T., Kim, S., Kurtén, T., Stratmann, F., Kerminen, V.-M., and Kulmala, M.: A new atmospherically relevant oxidant of sulphur dioxide, Nature, 488, 193-196 and the Supplement, 2012.

Montgomery Jr., J. A., Frisch, M. J., Ochterski, J. W., and Petersson, G. A.: A complete basis set model chemistry. VII. Use of the minimum population localization method, J. Chem. Phys., 112, 6532-6542, 2000.

O’Dowd, C. D., Jimenez, J. L., Bahreini, R., Flagan, R. C., Seinfeld, J. H., Hämeri, K., Pirjola, L., Kulmala, M., Jennings, S. G., and Hoffmann, T.: Marine particle formation from biogenic iodine emissions, Nature, 417, 632-636, 2002.
Ovadnevaite, J., Ceburnis, D., Leinert, S., Dall'Osto, M., Canagaratna, M., O’Doherty, S., Berresheim, H., and O'Dowd, C.: Distinct seasonal changes in marine aerosol composition and its properties, J. Geophys. Res. Atmos., 119, 11850-11863, doi:10.1002/2013JD021330, 2014.

Saiz-Lopez, A. and Plane, J. M. C.: Novel iodine chemistry in the marine boundary layer, Geophys. Res. Lett., 31, L04112, doi:10.1029/2003GL019215, 2004.

Saiz-Lopez, A., Plane, J. M. C., and Shillito, J. A.: Bromine oxide in the mid-latitude marine boundary layer, Geophys. Res. Lett., 31, L03111, doi:10.1029/2003GL018956, 2004.

Saiz-Lopez, A., Shillito, J. A., Coe, H., and Plane, J. M. C.: Measurements and modelling of $\mathrm{I}_{2}, \mathrm{IO}, \mathrm{OIO}, \mathrm{BrO}$ and $\mathrm{NO}_{3}$ in the mid-latitude marine boundary layer, Atmos. Chem. Phys., 6, 1513-1528, doi:10.5194/acp-6-1513-2006, 2006.

Sarwar, G., Simon, H., Fahey, K., Mathur, R., Goliff, W. S., and Stockwell, W. R.: Impact of sulfur dioxide oxidation by Stabilized Criegee Intermediate on sulfate, Atmos. Environ., 85, 204-214, 2014.

Saunders, S. M., Jenkin, M. E., Derwent, R. G., and Pilling, M. J.: Protocol for the development of the Master Chemical Mechanism, MCM v3 (Part A): tropospheric degradation of nonaromatic volatile organic compounds, Atmos. Chem. Phys., 3, 161-180, doi:10.5194/acp-3-161-2003, 2003.

Seguin, A. M., Norman, A.-L., Eaton, S., Wadleigh, M., and Sharma, S.: Elevated biogenic sulphur dioxide concentrations over the North Atlantic, Atmos. Environ., 44, 1139-1144, 2010.

Seinfeld, J. H. and Pandis, S. N.: Atmospheric Chemistry and Physics - From Air Pollution to Climate Change, chapters 8 and 11, J. Wiley \& Sons, New York, 452-490 and 596-647, 1998.

Schweitzer, F., Magi, L., Mirabel, P., and George, C.: Uptake rate measurements of methanesulfonic acid and glyoxal by aqueous droplets, J. Phys. Chem. A, 102, 593-600 1998.

Stone, D., Whalley, L. K., and Heard, D. E.: Tropospheric OH and $\mathrm{HO}_{2}$ radicals: field measurements and model comparisons, Chem. Soc. Rev., 41, 6348-6404, 2012.

Stone, D., Blitz, M., Daubney, L., Ingham, T., and Seakins, P.: $\mathrm{CH}_{2} \mathrm{OO}$ Criegee biradical yields following photolysis of $\mathrm{CH}_{2} \mathrm{I}_{2}$ in $\mathrm{O}_{2}$, Phys. Chem. Chem. Phys., 15, 19119-19124 2013.

Stone, D., Blitz, M., Daubney, L., Howes, N. U. M., and Seakins, P.: Kinetics of $\mathrm{CH}_{2} \mathrm{OO}$ reactions with $\mathrm{SO}_{2}, \mathrm{NO}_{2}, \mathrm{NO}, \mathrm{H}_{2} \mathrm{O}$ and $\mathrm{CH}_{3} \mathrm{CHO}$ as a function of pressure, Phys. Chem. Chem. Phys., 16, 1139-1149, 2014.

Taatjes, C. A., Welz, O., Eskola, A. J., Savee, J. D., Scheer, A. M., Shallcross, D. E., Rotavera, B., Lee, E. P. F., Dyke, J. M., Mok, D. K. W., Osborn, D. L., and Percival, C. $\mathrm{J}$.: Direct measurements of conformer-dependent reactivity of the Criegee intermediate $\mathrm{CH}_{3} \mathrm{CHOO}$, Science, 340, 177-180, doi:10.1126/science.1234689, 2013.

Taatjes, C. A., Shallcross, D. E., and Percival, C. J.: Research frontiers in the chemistry of Criegee intermediates and tropospheric ozonolysis, Phys. Chem. Chem. Phys., 16, 1704-1718, 2014.

Tanner, D. J. and Eisele, F. L.: Present $\mathrm{OH}$ measurement limits and associated uncertainties, J. Geophys. Res., 100, 2883-2892, 1995.

Vereecken, L., Harder, H., and Novelli, A.: The reaction of Criegee intermediates with $\mathrm{NO}, \mathrm{RO}_{2}$, and $\mathrm{SO}_{2}$, and their fate in the atmosphere, Phys. Chem. Chem. Phys., 14, 14682-14695, 2012. 
Welz, O., Savee, J. D., Osborn, D. L., Vasu, S. S., Percival, C., Shallcross, D. E., and Taatjes, C. A.:Direct kinetic measurements of Criegee intermediate $\left(\mathrm{CH}_{2} \mathrm{OO}\right)$ formed by reaction of $\mathrm{CH}_{2} \mathrm{I}$ with $\mathrm{O}_{2}$, Science, 335, 204-207, 2012. 